\title{
Dampak Pembangunan Infrastruktur dalam Mendorong Pertumbuhan untuk Mengurangi Tingkat Kemiskinan di Indonesia Tahun 2013 - 2017
}

\author{
Edi Victara Tinambunan*, Muhammad Findi, Yeti Lis Purnamadewi \\ Departemen Ilmu Ekonomi, Fakultas Ekonomi dan Manajemen, Institut Pertanian Bogor \\ Jalan Agatis, Kampus Darmaga, Bogor 16680, Indonesia \\ *Korespondensi: victara@gmail.com
}

[diterima: Agustus 2018- revisi: November 2018-diterbitkan daring: Juli 2019]

\begin{abstract}
ABSTRAK
Kemiskinan merupakan masalah sosial yang masih belum terselesaikan. Salah satu cara untuk mengatasi kemiskinan adalah melalui pembangunan infrastruktur yang merata dan tepat sasaran di seluruh Indonesia. Studi ini menganalisis pengaruh pengembangan infrastruktur terhadap kemiskinan melalui pertumbuhan ekonomi di Pulau Jawa dan luar Pulau Jawa. Alat analisis dalam penelitian ini menggunakan panel simultan dan tipologi klassen yang dilengkapi dengan 2 persamaan struktural. Hasil analisis studi ini menunjukkan bahwa infrastruktur listrik, pendidikan, transportasi dan air memengaruhi pertumbuhan ekonomi Pulau Jawa. Sementara itu, infrastruktur pendidikan, listrik, kesehatan dan transportasi memengaruhi pertumbuhan ekonomi di luar Pulau Jawa. Variabel populasi dan pertumbuhan ekonomi sama-sama memengaruhi kemiskinan di Pulau Jawa dan luar Pulau Jawa.
\end{abstract}

Kata Kunci : Infrastruktur; Kemiskinan; Luar Pulau Jawa; Pertumbuhan ekonomi; Pulau Jawa;

\begin{abstract}
Poverty is a social problem that has not been resolved until now. One way to overcome poverty is through equitable and targeted infrastructure development throughout Indonesia. This study analyzes the effect of infrastructure development on poverty through economic growth in Java and outside Java. The analytical tools in this study are simultaneous panel and typology klassen equipped with two structural equations. This study found that electricity, education, transportation and water infrastructure affect economic growth in Java. Meanwhile education, electricity, health and transportation infrastructure affect economic growth outside Java. Population and economic growth both affect poverty in Java and outside Java.
\end{abstract}

Keywords: Economic growth; Infrastructure; Java; poverty; outside Java.

JEL Classification: B22, H53, H54 


\section{PENDAHULUAN}

Kemiskinan adalah fenomena global yang muncul bukan hanya diakibatkan oleh kurangnya sumber daya tetapi juga timbul karena keterbatasan akses terhadap sumber daya, informasi, peluang, pemberdayaan, dan mobilitas (World Bank 1994). Masalah kemiskinan jika dibiarkan akan berdampak pada berbagai masalah sosial ekonomi seperti tingkat buta huruf serta pengangguran yang tinggi, tingkat kesehatan yang rendah dan buruknya lingkungan hidup. Salah satu strategi penanggulangan kemiskinan dapat dilakukan dengan pembangunan infrastruktur yang memadai.

Penelitian fokus untuk melihat pengaruh pembangunan infrastruktur yang menggunakan pertumbuhan ekonomi sebagai "jembatan" dalam mengurangi tingkat kemiskinan yang saat ini ada di Pulau Jawa juga di luar Pulau Jawa. Penelitian ini membandingkan jenis infrastruktur fisik apa yang sesuai dengan karakteristik daerah pada provinsi-provinsi di Jawa maupun yang ada di luar Pulau Jawa.

Gambar 1 menunjukkan kontribusi infrastruktur terhadap PDB dari tahun 2016 sampai 2018 yang diwakili oleh infrastruktur listrik, gas, air bersih dan komunikasi. kontribusi infrastruktur terhadap PDB cukup tinggi. Kontribusi infrastruktur juga di dukung dari peningkatan, dana alokasi infrastruktur dari tahun 2016 sampai 2018 yang selalu mengalami kenaikan. Hal ini menunjukkan pemerintah cukup serius dalam mendorong proses percepatan pembangunan infrastruktur yang ada di Indonesia. Tingginya kontribusi infrastruktur secara kumulatif terhadap PDB sejalan dengan realisasi anggaran infrastruktur yang selalu meningkat dari tahun ke tahun terhadap PDB dari tahun 2016 sampai 2018 selalu berada diatas pertumbuhan ekonomi Indonesia.

Saat ini pun jika dilihat berdasarkan tingkat kemiskinan di Indonesia dari tahun 2014 sampai 2018, terjadi kecenderungan penurunan tingkat kemiskinan dari tahun ke tahun. Pada tahun 2014 tingkat kemiskinan di Indonesia sebesar 10.96 persen dan mengalami peningkatan menjadi 11.13 persen di tahun 2015. Pada tahun 2016 tingkat kemiskinan turun menjadi 10.7 persen dan terus mengalami penurunan sampai tahun 2018. Penurunan tingkat kemiskinan ini mengindikasikan keberhasilan pemerintah dalam menekan kemiskinan.

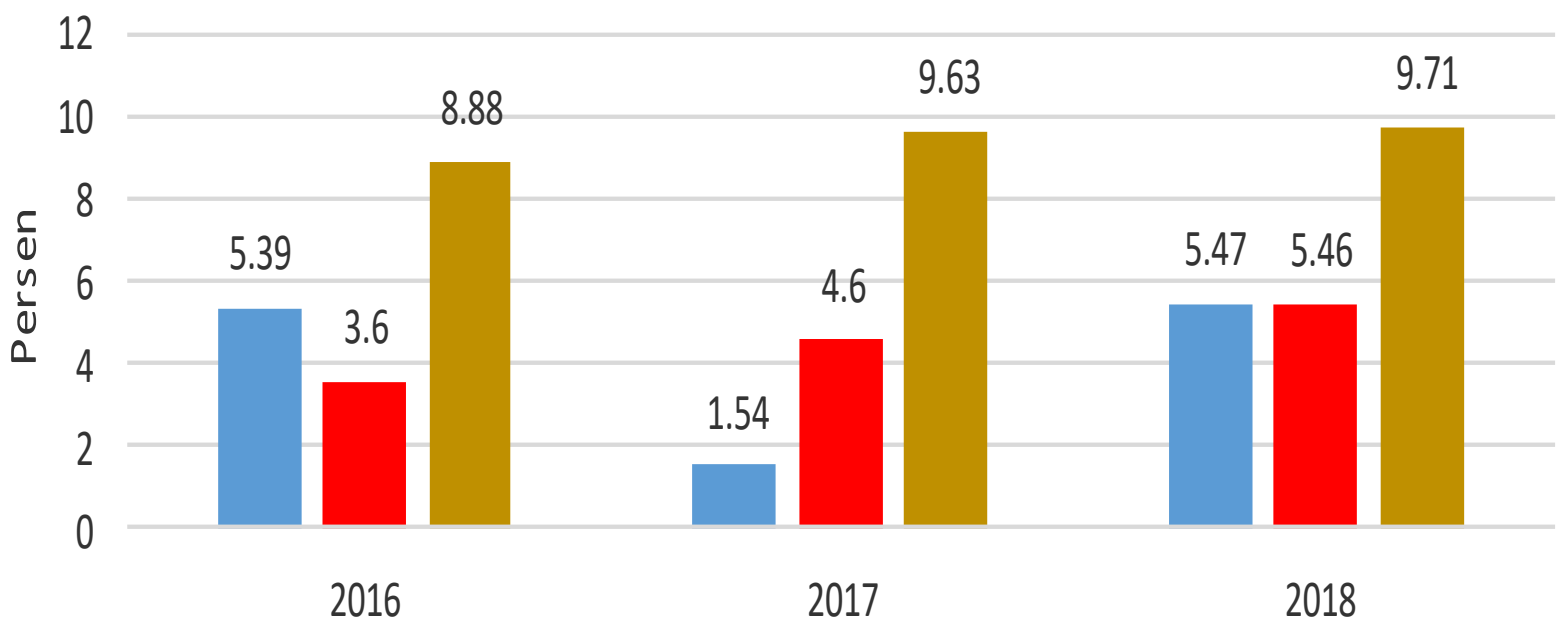

- Listrik dan Gas Air Bersih Komunikasi

Sumber : BPS, 2018 (diolah)

Gambar 1. Kontribusi infrastruktur pada PDB berdasarkan harga konstan tahun 2010 (persen).

Salah satu caranya dilakukan dengan penurunan tingkat kemiskinan pada tahun 2014 pembangunan infrastruktur sampai ke seluruh sampai 2018, laju penurunan tingkat kemiskinan pelosok Indonesia, namun jika dilihat dari tersebut masih bersifat fluktuatif dan belum 
konsisten. Penurunan tersebut bahkan semakin mengecil dari tahun ke tahun.

Hal ini menunjukkan permasalahan kemiskinan di Indonesia belum sepenuhnya dapat terselesaikan, dibutuhkan kebijakan dan program pengentasan kemiskinan yang tepat sasaran sehingga anggaran dana yang dikeluarkan pemerintah tidak sia-sia. Masalah kemiskinan yang ada di Indonesia bukan hanya menjadi tanggung jawab satu individu ataupun kelompok saja, namun merupakan tanggung jawab negara. Menurut UUD tahun 1945 pasal 34 ayat 1 negara memiliki kewajiban untuk memelihara fakir miskin dan anak terlantar.

Faktanya pada Gambar 2 daerah yang mempunyai keadaan infrastruktur atau akumulasi kapital yang lebih memadai juga mempunyai pertumbuhan ekonomi yang juga lebih baik (Maryaningsih et al 2014). Adanya ketersediaan infrastruktur akan menunjang peningkatan produktivitas untuk setiap faktor-faktor produksi yang merupakan faktor kunci dalam mendukung pertumbuhan ekonomi. Berdasarkan data yang didapat dari BPS menunjukkan bahwa Pulau Jawa memberikan share yang lebih banyak pada PDB Indonesia walaupun hanya terdiri dari enam provinsi, terkait keadaan infrastruktur Pulau Jawa saat ini memiliki infrastruktur yang juga lebih baik dibandingkan dengan pulau lainnya sehingga memiliki hubungan yang linier antara keadaan infrastruktur dan kontribusi PDRB yang diberikan Jawa.

Pada masa pemerintahan Joko Widodo pembangunan infrastruktur sampai ke pelosok Indonesia terus dilakukan untuk mendorong pertumbuhan ekonomi wilayah dan mengejar tingkat ketimpangan ekonomi antar wilayah yang terjadi antara provinsi yang ada di Pulau Jawa dan di daerah diluar Pulau Jawa. Proses pembangunan dari pinggiran ini terbukti pada pembangunan 21 dari 30 mega proyek yang dibangun di luar Pulau Jawa pada tahun 2016 dan 2017 yang menghabiskan dana sebesar 94.8 triliun rupiah.

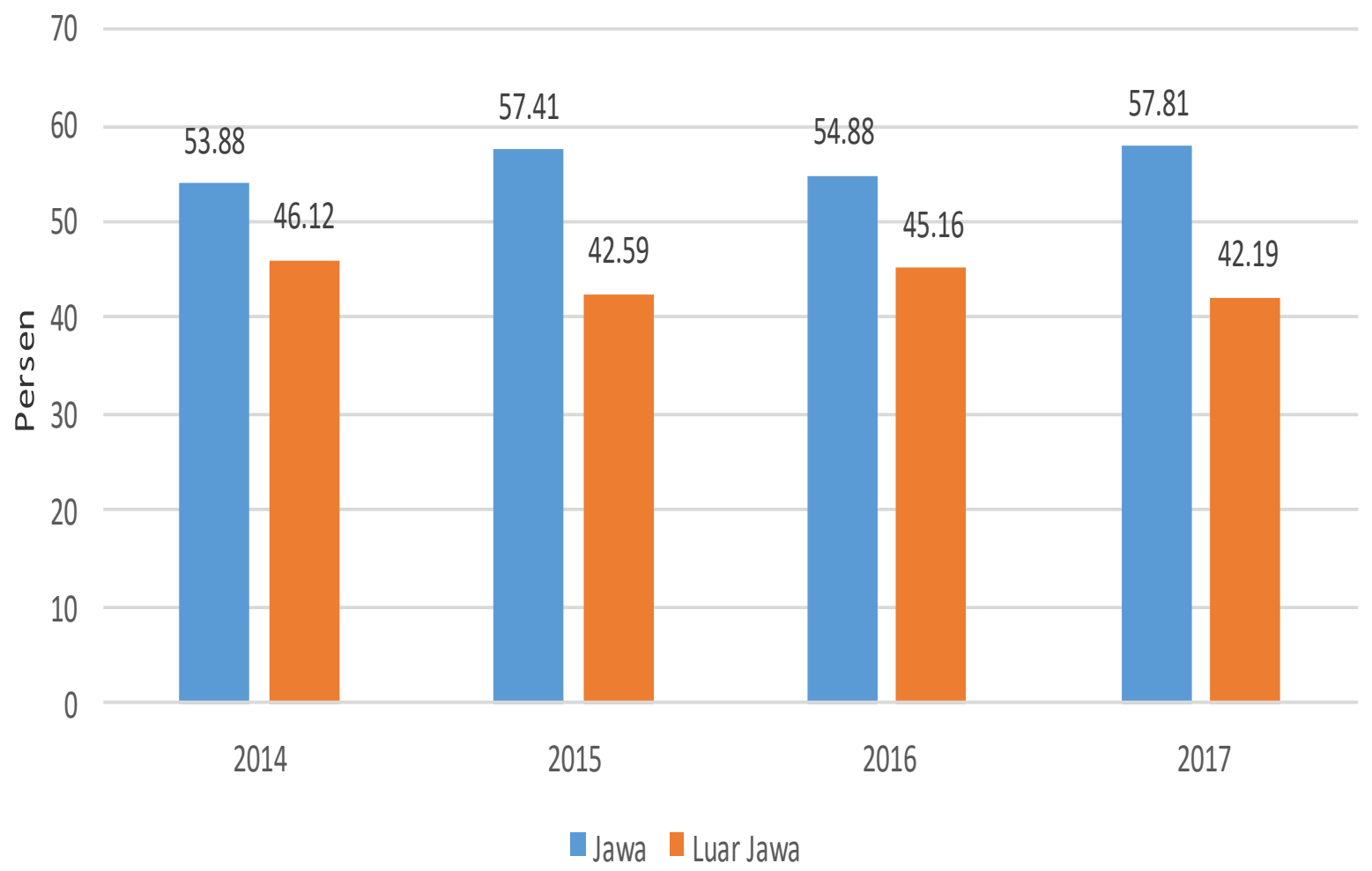

Sumber: BPS, 2018 (diolah)

Gambar 2. Persentase kontribusi PDRB Pulau Jawa dan luar Pulau Jawa terhadap PDB Indonesia tahun 2014 sampai 2017.

Pembangunan infrastruktur yang masif tersebut diluar Pulau Jawa bertujuan untuk meningkatkan akses kehidupan yang lebih layak serta pembukaan sumber daya ekonomi yang baru bagi masyarakat miskin serta mampu mengurangi tingkat kemiskinan terutama di 
wilayah-wilayah tempat kantong kemiskinan Indonesia berada seperti provinsi NTT atau provinsi yang ada di Pulau Papua. Hal ini yang juga yang mendasari penulis untuk mendikotomi fokus penelitian ini untuk meneliti pengaruh infrastruktur di Pulau Jawa dan luar Pulau Jawa.

Dilihat dari jumlah penduduk miskin, Pulau Jawa justru mempunyai tingkat kemiskinan yang lebih tinggi dari pada pulau-pulau lainnya, jumlah nominal penduduk miskin di Pulau Jawa selalu berada di atas 50 persen dari tahun 2014 sampai 2017. Hal ini bertolak belakang dengan kontribusi PDRB dan keadaan infrastruktur yang ada di Pulau Jawa yang lebih lengkap ketersediaanya dari pada di pulau lainnya. Tingginya penduduk miskin di Pulau Jawa tidak terlepas dari fakta bahwa banyaknya penduduk Indonesia yang tinggal di pulau ini.

Ada beberapa faktor yang mendorong tingginya tingkat migrasi seperti jumlah ketersediaan dan keterbukaan lapangan pekerjaan yang lebih besar, keadaan infrastruktur, layanan publik yang lebih baik, transportasi memadai dan jasa di Pulau Jawa yang lebih baik sehingga mendorong penduduk diluar Pulau Jawa untuk melakukan migrasi ke Pulau Jawa. Dari informasi yang sudah dipaparkan maka dapat diambil kesimpulan bahwa pembangunan infrastruktur sangat penting dalam mengentaskan kemiskinan yang ada di Indonesia, pentingnya peranan infrastruktur terhadap pertumbuhan ekonomi mendorong penulis untuk melakukan penelitian terhadap pengaruh pembangunan infrastruktur untuk mengurangi kemiskinan lewat pertumbuhan ekonomi.

Berdasarkan pemaparan informasi yang sudah dijelaskan tujuan penelitian ini yaitu (1) Mengetahui keadaan pola struktur pembangunan infrastruktur dan kemiskinan di Indonesia tahun 2013 sampai 2017. (2) Mengukur dampak pembangunan infrastruktur terhadap tingkat PDRB di Pulau Jawa dan di luar Pulau Jawa. (3) Mengukur dampak tingkat PDRB terhadap pengentasan kemiskinan di Pulau Jawa dan luar Jawa.

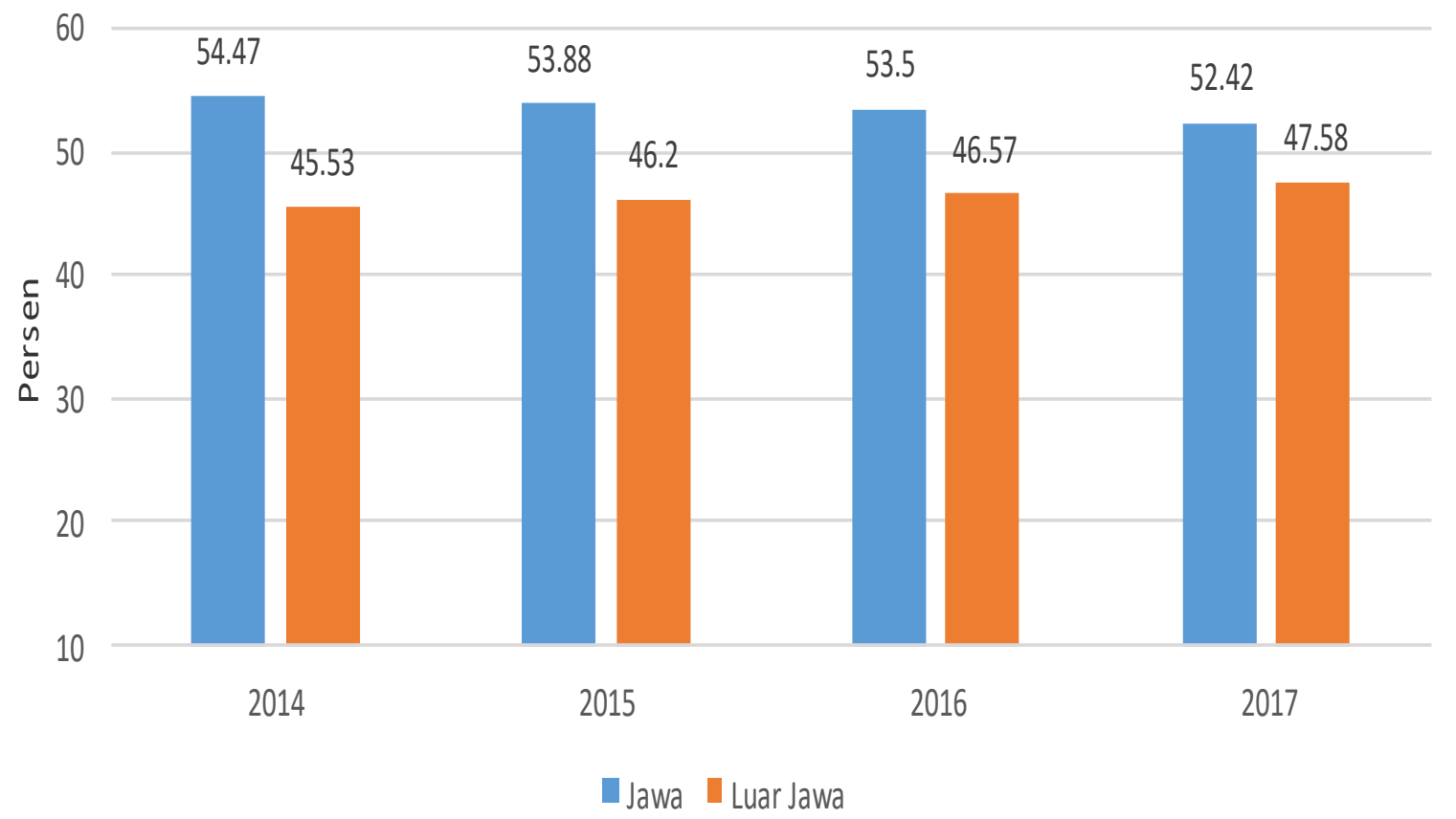

Sumber: BPS, 2018 (diolah)

Gambar 3. Kontribusi persentase tingkat kemiskinan Pulau Jawa dan luar Pulau Jawa.

\section{TINJAUAN PUSTAKA}

\section{Pertumbuhan Ekonomi}

Pada dasarnya pertumbuhan ekonomi merupakan kenaikan dari pendapatan riil secara berkelanjutan melalui peningkatan kapasitas produksi. Pertumbuhan ekonomi dapat diukur melalui peningkatan nilai output produksi barang dan jasa dalam suatu kegiatan ekonomi. Dalam penyajiannya terdapat dua jenis PDRB yaitu PDRB atas dasar harga berlaku dan PDRB atas dasar harga konstan. PDRB atas dasar harga 
berlaku (ADHB) menghitung nilai tambah ouput dengan menggunakan harga pada tahun berjalan sehingga ADHB digunakan untuk mengetahui pergeseran dan struktur ekonomi suatu daerah. Pertumbuhan ekonomi tersebut dapat diukur secara keseluruhan atau sektoral.

Selanjutnya ada PDRB atas dasar harga konstan (ADHK) yang digunakan untuk menghitung nilai tambah ouput menggunakan harga tahun dasar tertentu sehingga digunakan untuk mengetahui pertumbuhan ekonomi dari tahun ke tahun baik keseluruhan maupun setiap sektor ekonomi. Maka dari itu pada PDRB ADHK pengaruh perbedaan harga antarwaktu telah dihilangkan.

Todaro dan Smith (2008) mendefinisikan pertumbuhan ekonomi sebagai suatu proses peningkatan kapasitas produktif dalam suatu perekonomian secara terus-menerus atau berkesinambungan sepanjang waktu sehingga menghasilkan tingkat pendapatan dan output nasional yang semakin lama semakin besar. Terdapat tiga komponen utama dalam pertumbuhan ekonomi, yaitu:

1. Akumulasi modal meliputi semua bentuk investasi baru yang ditanamkan pada tanah, peralatan fisik dan sumber daya manusia melalui perbaikan dibidang kesehatan, pendidikan dan keterampilan kerja.

2. Pertumbuhan jumlah penduduk yang pada akhirnya menyebabkan pertumbuhan angkatan kerja.

3. Kemajuan teknologi yang secara luas diartikan sebagai cara baru dalam menyelesaikan pekerjaan.

\section{Kemiskinan}

Kemiskinan pada umumnya memiliki dua dimensi yakni dimensi pendapatan dan dimensi non pendapatan. Kemiskinan pendapatan didefinisikan sebagai keluarga yang memiliki pendapatan rendah yang diukur dari kepemilikan harta kekayaan dan kesulitan dalam mengakses jasa pelayanan publik. Sedangkan kemiskinan non pendapatan adanya ketidakmampuan, ketiadaan harapan, tidak adanya perwakilan dan kebebasan yang dapat menimpa pada berbagai level pendapatan.

Sampai saat ini ada beberapa penelitian terdahulu yang sudah melakukan penelitian terhadap pengaruh pembangunan infrastruktur terhadap kemiskinan diantaranya adalah penelitian yang dilakukan Calderon dan Serven (2004) penelitiannya tentang efek pembangunan infrastruktur terhadap pertumbuhan PDB dan distribusi pendapatan. Metode yang digunakan adalah analisis panel data dinamis (GMM) menggunakan estimasi persamaan sederhana untuk pertumbuhan PDB dengan menyertakan kualitas dan kuantitas infrastruktur di 121 negara tahun 1960 hingga 2000. Hasil penelitiannya menyatakan bahwa pertumbuhan ekonomi positif dipengaruhi oleh persediaan aset dari infrastruktur (kuantitas), dan ketimpangan pendapatan menurun seiring dengan kuantitas dan kualitas infrastruktur yang meningkat.

Penelitian yang dilakukan oleh Priyarsono (2012) menguji bagaimana keterkaitan antara infrastruktur dan kemiskinan di Indonesia. Variabel infrastruktur yang digunakan pada penelitian tersebut adalah akses rumah tangga terhadap listrik, akses rumah tangga terhadap air bersih dan panjang jalan dengan kondisi baik per luas wilayah. Penelitian ini menggunakan metode panel data dengan ruang lingkup 200 kabupaten/kota dan rentang waktu 2006-2009. Hasil penelitian menunjukan bahwa ketiga variabel infrastruktur tersebut berpengaruh negatif dan signifikan terhadap persentase penduduk miskin di Indonesia.

Chotia dan Rao (2016) yang meneliti tentang keterkaitan antara pembangunan infrastruktur, kemiksinan dan ketimpangan pendapatan di negara-negara BRICS (Brazil, Rusia, India, Cina dan Afrika Selatan) pada tahun penelitian 2007 hingga 2015 menggunakan alat analisis panel data dinamis dimana dalam pengujian hasil penelitian tersebut didapatkan variabel infrastruktur air bersih dan sanitasi, energi, telekomunikasi dan transportasi dapat mengurangi tingkat kemiskinan yang ada di daerah tersebut namun tidak pada tingkat ketimpangan ekonominya.

\section{METODE Jenis dan Sumber Data}

Penelitian ini memakai data sekunder deret lintang dan deret waktu, tahun 2013 sampai 2017 pada 33 provinsi (tidak termasuk Kalimantan Utara) yang ada di Indonesia. Data di dikotomi 
menjadi 6 provinsi di Pulau Jawa dan 27 provinsi lainnya di luar Pulau Jawa . Data didapatkan dari Badan Pusat Statistika (BPS) dan sumber referensi pendukung lainnya.

\section{Metode Analisis dan Pengolahan Data}

Studi ini menggunakan metode analisis kuantitatif dan deskriptif. Metode deskriptif digunakan untuk menjelaskan dan mempermudah dalam menafsirkan data kuantitatif. Metode kuantitatif digunakan untuk melihat dampak ketersediaan infrastruktur dalam mendorong pertumbuhan ekonomi dan menekan angka kemiskinan pada provinsi yang terletak di Pulau Jawa dan juga diluar Pulau Jawa.

Studi ini menggunakan dua model persamaan simultan 2SLS (Two-Stage Least Square), sebagai berikut:

$$
\begin{aligned}
& \mathrm{LnPDRB}_{\mathrm{it}}={ }_{\alpha 0}+{ }_{\alpha 1} \mathrm{LnAir}_{\mathrm{it}}+{ }_{\alpha 2} \mathrm{LnJ}_{\mathrm{it}}+{ }_{\alpha 3} \mathrm{LNKes}_{\mathrm{it}} \\
& +_{\alpha 4} \mathrm{Lis}_{\mathrm{it}}+{ }_{\alpha 5} \mathrm{LnPendi}_{\mathrm{it}}+{ }_{\alpha 6} \mathrm{LnTK}_{\mathrm{it}}+ \\
& \mathrm{u}_{\mathrm{it}} \\
& \operatorname{LnPov}_{i t}={ }_{\beta 0}+{ }_{\beta 1} \operatorname{LnPDRB}_{i t}+{ }_{\beta 2} \operatorname{LnUMP}_{i t}+{ }_{\beta 3} \\
& \mathrm{GINI}_{\mathrm{it}}+{ }_{\beta 4} \mathrm{LnPOP}_{\mathrm{it}}+{ }_{\beta 5} \mathrm{LnAHH}_{\mathrm{it}}+ \\
& \varepsilon_{\text {it }}
\end{aligned}
$$

Keterangan:

PDRB : Bruto atas dasar harga konstan 2010 (rupiah)

Air : Volume distribusi air Bersih yang disalurkan PDAM (ribu $\mathrm{m}^{3}$ )

JL : Panjang jalan menurut Tingkat kewenangan dengan keadaan Baik $\left(\mathrm{Km}^{2}\right)$

Kes : Jumlah rumah sakit dan puskesmas (unit)

Lis : Rasio elektrifikasi (persen)

Pendi : Rata-rata lama sekolah (tahun)

TK : Jumlah tenaga kerja (jiwa)

Pov : Jumlah penduduk miskin (jiwa)
UMP : Upah minimum provinsi (rupiah)

GINI : Tingkat ketimpangan (Indeks)

POP : Jumlah Penduduk (Jiwa)

AHH : Angka Harapan Hidup (Tahun)

ai, $\beta \mathrm{i}^{-} \beta 5:$ : Parameter yang diduga

i : Cross section 33 provinsi (Pulau Jawa dan luar Pulau Jawa)

$t$

Time Series 5 tahun ( 2013-2017)

\section{Identifikasi Model}

Pada model persamaan simultan, identifikasi model ini ditentukan berdasarkan dua hal yaitu order condition jadi prasyarat pertama dan rank condition jadi prasyarat selanjutnya. Dalam suatu persamaan dapat terjadi 3 kemungkinan identifikasi, yaitu persamaan dinyatakan secara tepat (exactly identified), secara berlebih (over identified) atau tidak teridentifikasi (unidentified). Rumus identifikasi model struktural persamaan simultan pada tahap order condition dilakukan dengan tiga cara, yaitu:

Rumus Identifikasi : $(\mathrm{K}-\mathrm{M}) \geq(\mathrm{G}-1)$

1. Apabila hasil identifikasi (K-M) > (G-1) dikategorikan sebagai over identified

2. Apabila hasil identifikasi $(\mathrm{K}-\mathrm{M})=(\mathrm{G}-1)$ dikategorikan sebagai exactly identified

3. Apabila hasil identifikasi (K-M) < (G-1) dikategorikan sebagai unidentified

Keterangan:

K : Total semua variabel pada model (peubah predetermined dan endogen)

M : Total variabel eksogen dan endogen dalam model persamaan tertentu

G : Total variabel endogen yang digunaka pada model atau total model

Tabel 1. Hasil Identifikasi Model persamaan structural.

\begin{tabular}{lllllll}
\hline Nama Persamaan & K & M & G & K-M & G-m & Kategori \\
\hline PDRB & 10 & 6 & 2 & 4 & 1 & Over Identified
\end{tabular}




\section{HASIL PEMBAHASAN \\ Gambaran Umum}

\section{Pertumbuhan ekonomi}

Produk Domestik Bruto (PDB) sering dianggap sebagai ukuran terbaik untuk mengukur kinerja perekonomian. Tujuan dari perhitungan PDB adalah meringkas aktivitas ekonomi di suatu wilayah dalam suatu nilai uang tertentu selama periode waktu tertentu.
Pada gambar 4 tingkat pertumbuhan ekonomi yang ada di Pulau Jawa dan luar Pulau Jawa dari tahun 2013 sampai 2017, rata-rata tingkat pertumbuhan ekonominya hampir sama. Dari tahun 2013 sampai 2015 pertumbuhan ekonomi di Pulau Jawa lebih baik, kemudian di tahun selanjutnya pertumbuhan diluar Jawa lebih tinggi.

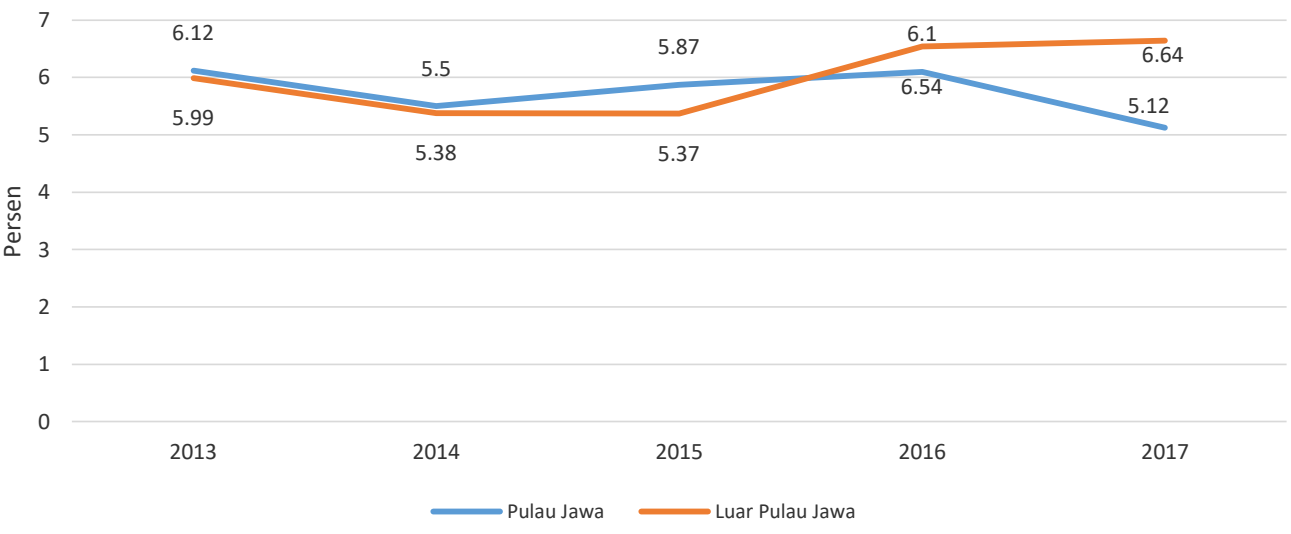

Sumber: BPS, 2018 (diolah)

Gambar 4. Tingkat pertumbuhan ekonomi Pulau Jawa dan luar Pulau Jawa tahun 2013-2017.

Jika diukur berdasarkan pertumbuhan tertinggi di Pulau Jawa dari tahun 2013 sampai ekonomi pada provinsi yang ada di Pulau Jawa, 2017. Hal ini terjadi karena peningkatan tingkat pertumbuhan ekonominya cukup konsumsi rumah tangga dan investor di sisi beragam. Provinsi Banten menjadi provinsi pengeluaran pada 5 tahun tersebut. dengan rata-rata tingkat pertumbuhan ekonomi

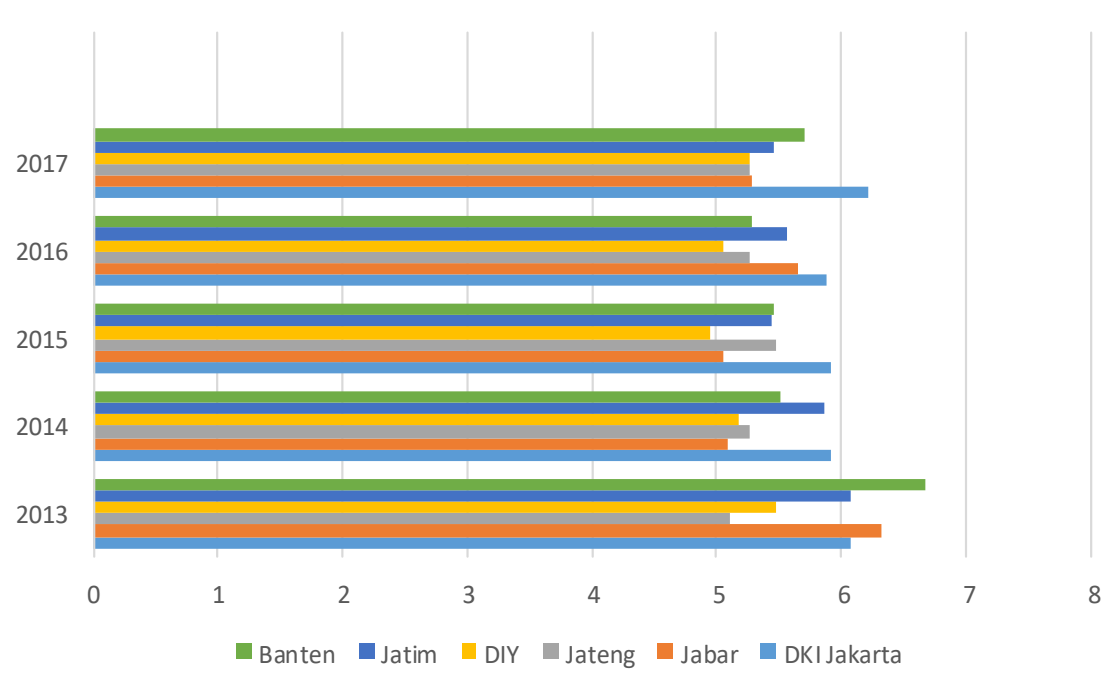

Sumber : BPS, 2018 (diolah)

Gambar 5. Tingkat pertumbuhan ekonomi provinsi di Pulau Jawa tahun 2013-2017 
Sementara itu pada Gambar 5 provinsi dengan tingkat pertumbuhan ekonomi terendah ada pada provinsi Daerah Istimewa Yogyakarta. Pada 5 tahun tersebut tingkat pertumbuhan ekonomi di wilayah tersebut tumbuh dengan rata-rata di angka 5 persen. Hal ini bertolak belakang dengan kenyataan bahwa provinsi Daerah Istimewa Yogyakarta sebagai salah satu tempat wisata yang sering didatangi turis dan berpotensi sebagai faktor pendorong pertumbuhan ekonomi di wilayah tersebut.

Jika ditinjau pada Gambar 6 rata-rata pertumbuhan ekonomi provinsi yang ada di Pulau Jawa juga lebih besar jika dibandingkan dengan rata-rata pertumbuhan ekonomi yang ada di luar Pulau Jawa dan ini berpotensi mendorong timbulnya ketimpangan wilayah. Banyak yang beranggapan, meningkatnya ketimpangan adalah hal yang wajar.

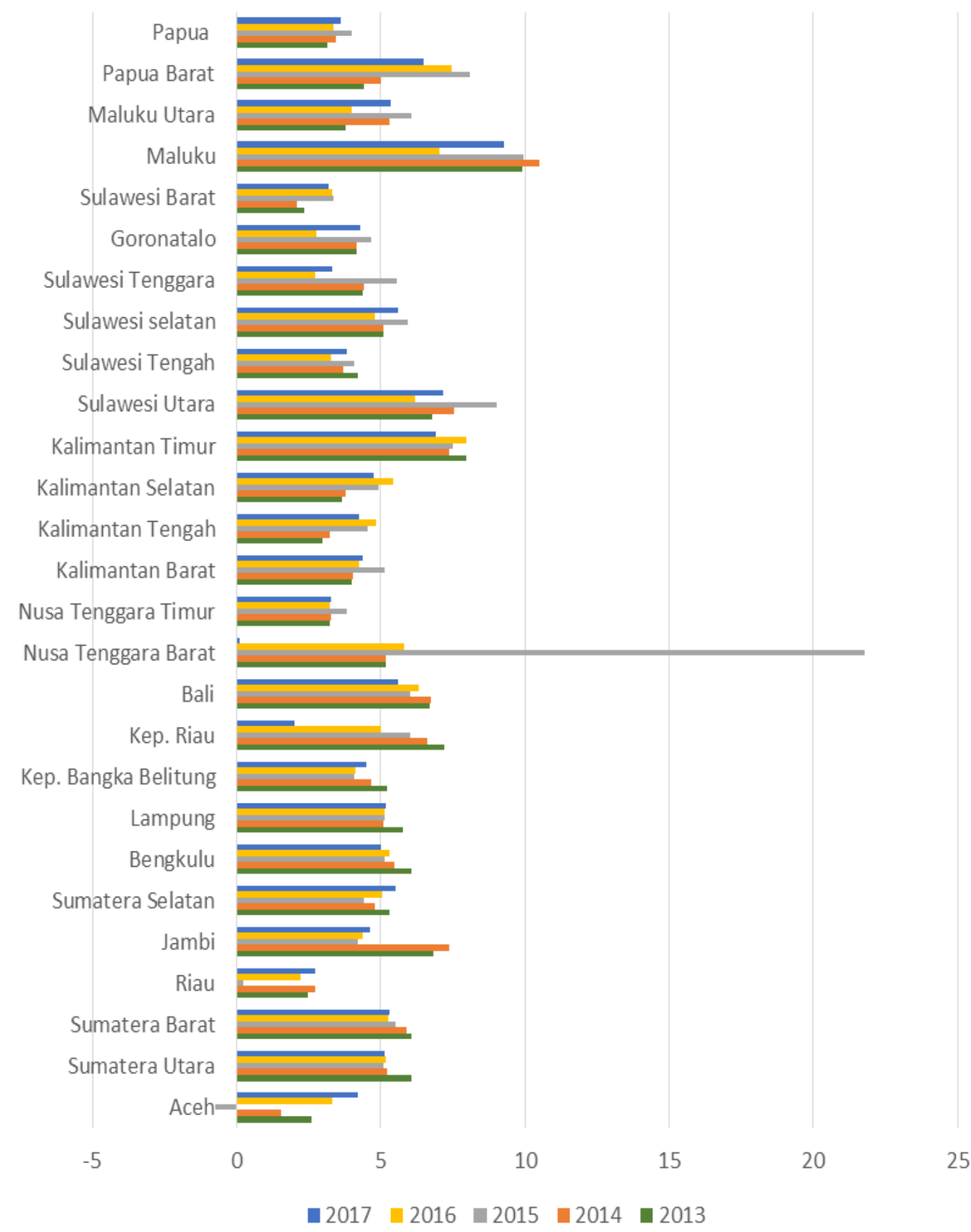

Sumber : BPS, 2018 (diolah)

Gambar 6. Tingkat Pertumbuhan ekonomi di provinsi-provinsi yang ada di luar Pulau Jawa tahun 2013 sampai 2017 
Khususnya pada negara yang sedang berkembang. Ini terjadi karena pertumbuhan ekonomi memerlukan kapital yang pembentukannya memerlukan tabungan masyarakat. Tumbuhnya golongan kaya memungkinkan akumulasi kapital terjadi lebih cepat.

Di sisi lain pertumbuhan ekonomi yang inklusif dianggap menjadi faktor penting untuk mengurangi kemiskinan dan menekan tingkat ketimpangan ekonomi di suatu wilayah, pertumbuhan ekonomi inklusif yang tidak hanya dirasakan oleh segelintir masyarakat yang memiliki tingkat pendapatan menengah keatas, tapi juga seluruh lapisan masyarakat. Sebagaimana sesuai dengan tujuan diadakannya otonomi daerah yang pembangunan daerahnya diserahkan pada pemerintah daerahnya masingmasing. Perubahan pola pemerintahan sejak dikeluarkannya UU No. 22 Tahun 1999 membawa dimensi baru dalam pembangunan dan penyediaan pelayanan infrastruktur yang berbasis pada daerahnya masing-masing.

\section{Infrastruktur}

\section{Infrastruktur Listrik}

Total energi listrik yang terjual pada Gambar 7 di Pulau Jawa lebih banyak dibandingkan di luar Pulau Jawa. Hal ini disebabkan karena jumlah penduduk, kepadatan rumah tangga serta aktivitas industri lebih banyak ada di Pulau Jawa, sering ditemukan beberapa wilayah yang ada diluar Pulau Jawa belum mendapat aliran listrik.

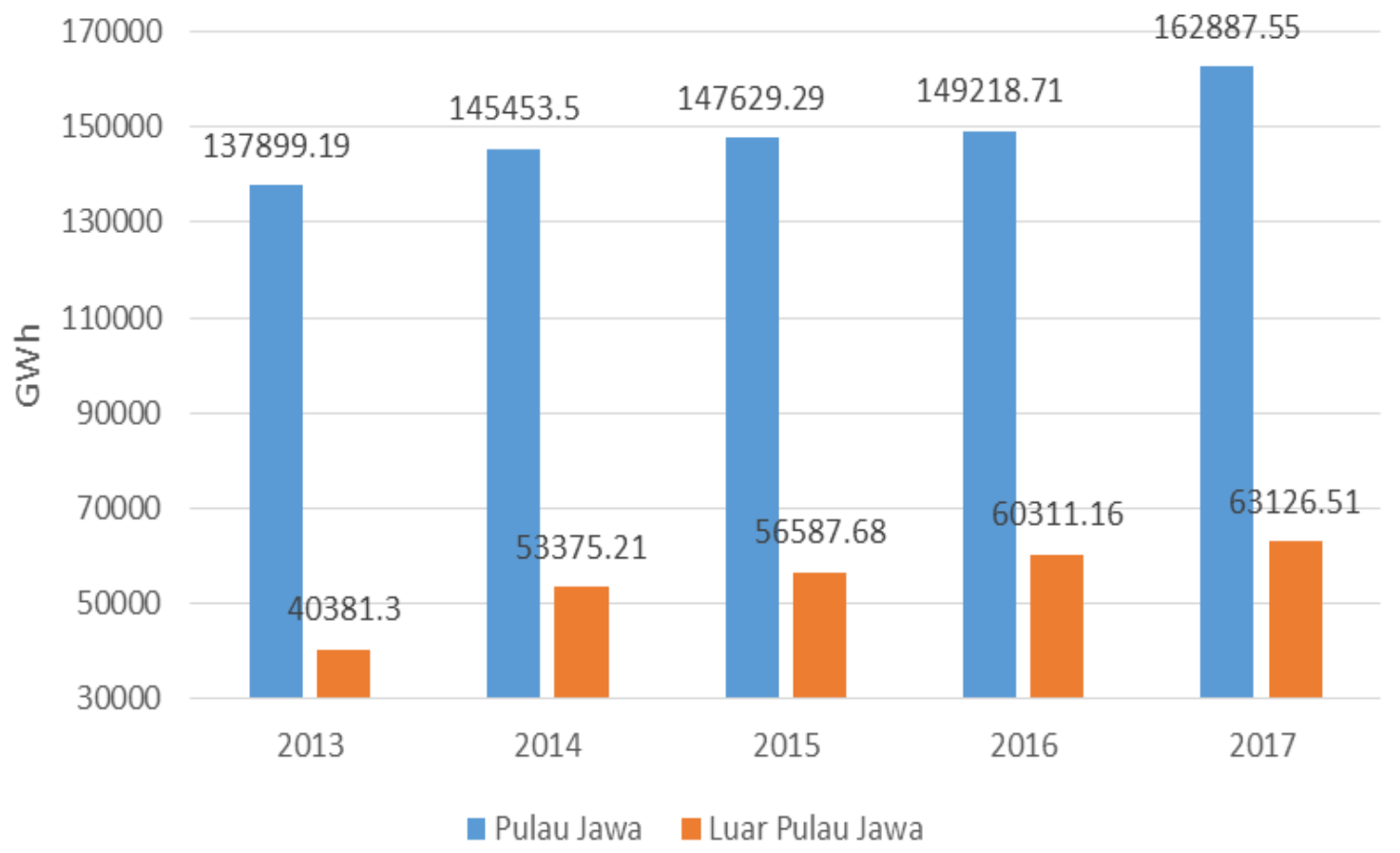

Gambar 7. Distribusi Listrik Pulau Jawa dan luar Pulau Jawa.

Berdasarkan tipologi klassen, di Pulau Jawa saat ini provinsi dengan pelanggan listrik lebih banyak terdapat pada kuadran IV yaitu wilayah maju tapi tertekan. Rasio elektrifikasinya tinggi namun pertumbuhannya rendah, provinsi tersebut adalah DKI Jakarta, Jawa Barat dan Jawa Timur yang sudah menjadi pusat industri utama di Pulau Jawa seperti industri kulit sepatu dan pengolahan makanan yang juga menjadi sumber pendapatan utama pada sektor yang ada di Pulau Jawa.

Pada Gambar 8, provinsi yang ada di luar Pulau Jawa, rasio elektrifikasinya tidak sebanyak provinsi-provinsi yang ada di Pulau Jawa. Berdasarkan klasifikasi tipologi klassen sebagian besar pelanggan listrik yang ada diluar Pulau Jawa terdapat pada wilayah kuadran II.

Dominannya rasio elektrifikasi yang didistribusikan ke wilayah II dalam jangka panjang akan berdampak baik pada pengurangan tingkat ketimpangan wilayah yang ada di Indonesia karena daerah tersebut akan berkembang dan mengejar provinsi yang terdapat pada kuadran I yaitu daerah maju dan berkembang cepat. 


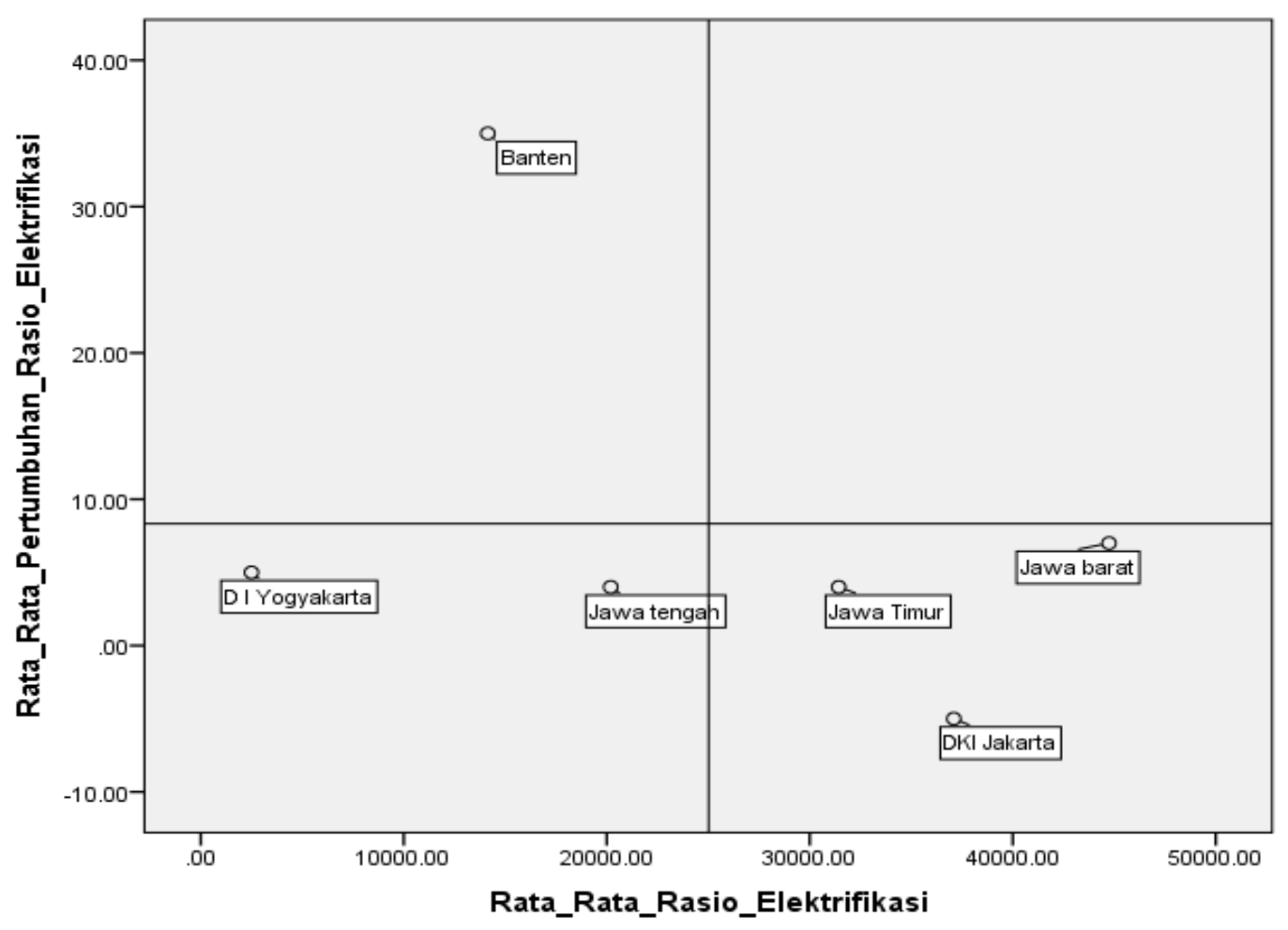

Gambar 8. Klasifikasi pertumbuhan pelanggan listrik provinsi di pulau Jawa tahun 2013-2017 menurut Tipologi Klassen.

Peningkatan pertumbuhan rasio elektrifikasi yang dialirkan didaerah ini akan mendorong pertumbuhan ekonomi di wilayah tersebut dan mengurangi tingkat ketimpangan wilayah antar provinsi terutama dengan provinsi yang terdapat di Pulau Jawa. Dalam hal ini pemerintah lewat Perusahaan listrik negara juga harus memberikan perhatian pada pendistribusian listrik terutama di daerah yang ada di Timur Indonesia.

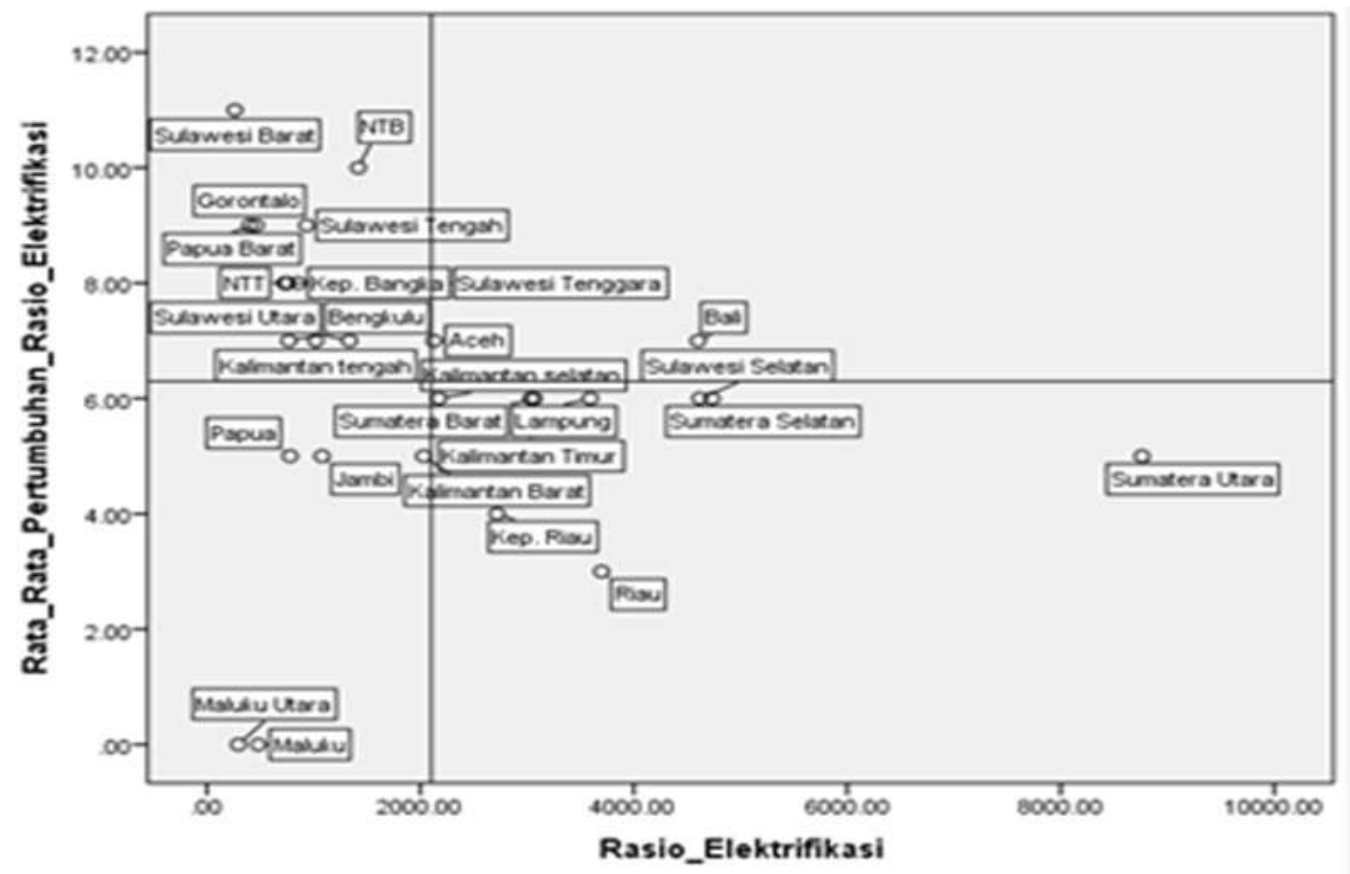

Gambar 9. Klasifikasi pertumbuhan pelanggan listrik provinsi di luar Pulau Jawa tahun 2013 - 2017 menurut Tipologi Klassen. 
Pada Gambar 9, dalam hal ini pemerintah lewat Perusahaan listrik negara juga harus memberikan perhatian pada pendistribusian listrik terutama di daerah yang ada di Timur Indonesia seperti Papua dan Maluku yang termasuk dalam wilayah relatif tertinggal.

\section{Infrastruktur Air}

Secara ringkas air merupakan kebutuhan dasar yang harus dipenuhi ketersediannya. Peran air bersih dalam industri dan niaga adalah sebagai pendorong terselenggaranya sektor-sektor usaha. Peran air bersih dalam sosial dan non niaga adalah sebagai penunjang kehidupan masyarakat yang berkualitas khususnya perihal kesehatan.

Jika dilihat dari Gambar 10 volume air bersih yang disalurkan perusahaan air bersih dalam negeri menunjukkan bahwa banyaknya volume air bersih yang disalurkan PDAM di Jawa lebih banyak daripada luar Pulau Jawa pada periode 2013-2017 Jika dilihat pola persebesaran distribusi air bersih berdasarkan tipologi Klassen pada Pulau Jawa maka dapat dilihat bahwa distribusi volume air bersih lebih banyak terdapat pada wilayah kuadran I yaitu daerah maju dan cepat tumbuh. Provinsi DKI Jakarta, Jawa Barat dan Jawa Timur yang juga merupakan provinsi dengan jumlah penduduk terbanyak di Indonesia.

Dalam jangka panjang hal ini berdampak positif terhadap pertumbuhan ekonomi Indonesia karena daerah tersebut akan memberikan kontribusi terlebih 3 provinsi tersebut juga merupakan pusat-pusat perekonomian, namun hal tersebut akan berpengaruh negatif terhadap tingkat ketimpangan wilayah karena wilayah yang seharusnya menjadi prioritas dalam penyediaan air bersih (Kuadran III) justru ketersediaan air bersihnya masih minim. Hal ini juga terkonfirmasi dari beberapa kasus kekurangan air bersih yang terjadi pada Provinsi Banten dimana terdapat beberapa kecamatan di kabupaten Lebak dan Cilegon yang mengalami krisis air.

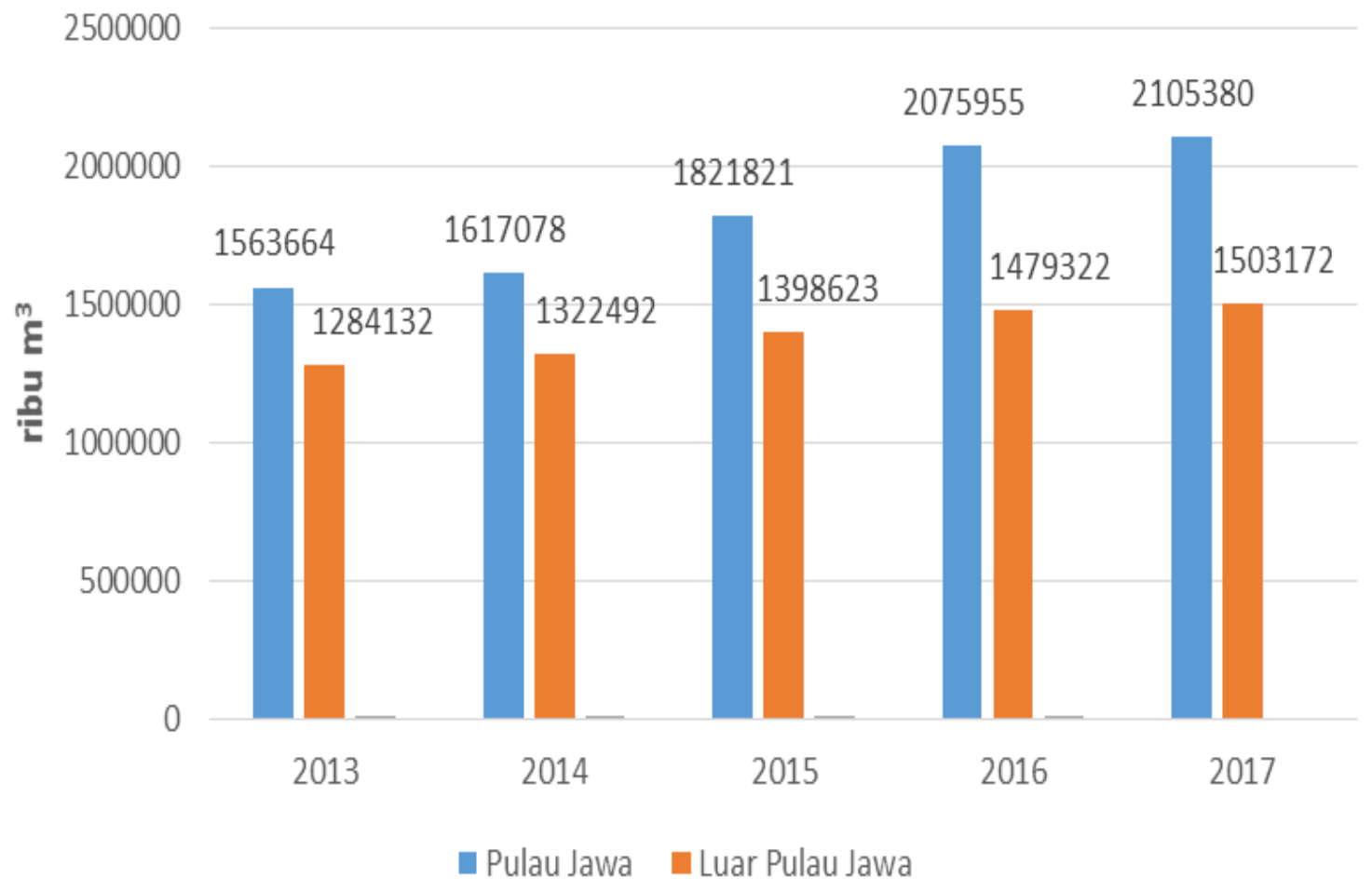

Gambar 10. Volume air bersih yang disalurkan perusahaan air bersih di Pulau Jawa dan luar Pulau Jawa tahun 2013-2017.

Pada Gambar 11, provinsi yang ada di luar Pulau Jawa sebagian besar distribusi air bersih ada pada wilayah kuadran II yaitu daerah berkembang cepat tapi tidak maju. Pertumbuhan volume airnya mengalami peningkatan yang cukup tinggi dari tahun 2012 sampai 2017 namun jumlah volume airnya tidak sebesar provinsiprovinsi yang ada pada kuadran I dan IV. 
Dalam Jangka panjang hal ini akan akhirnya dapat mendorong pertumbuhan memberikan dampak positif pada wilayah ekonomi di wilayah tersebut dan mengurangi tersebut karena dapat mengejar ketersedian tingkat ketimpangan antar wilayah.

infrastruktur air pada wilayah I, yang pada

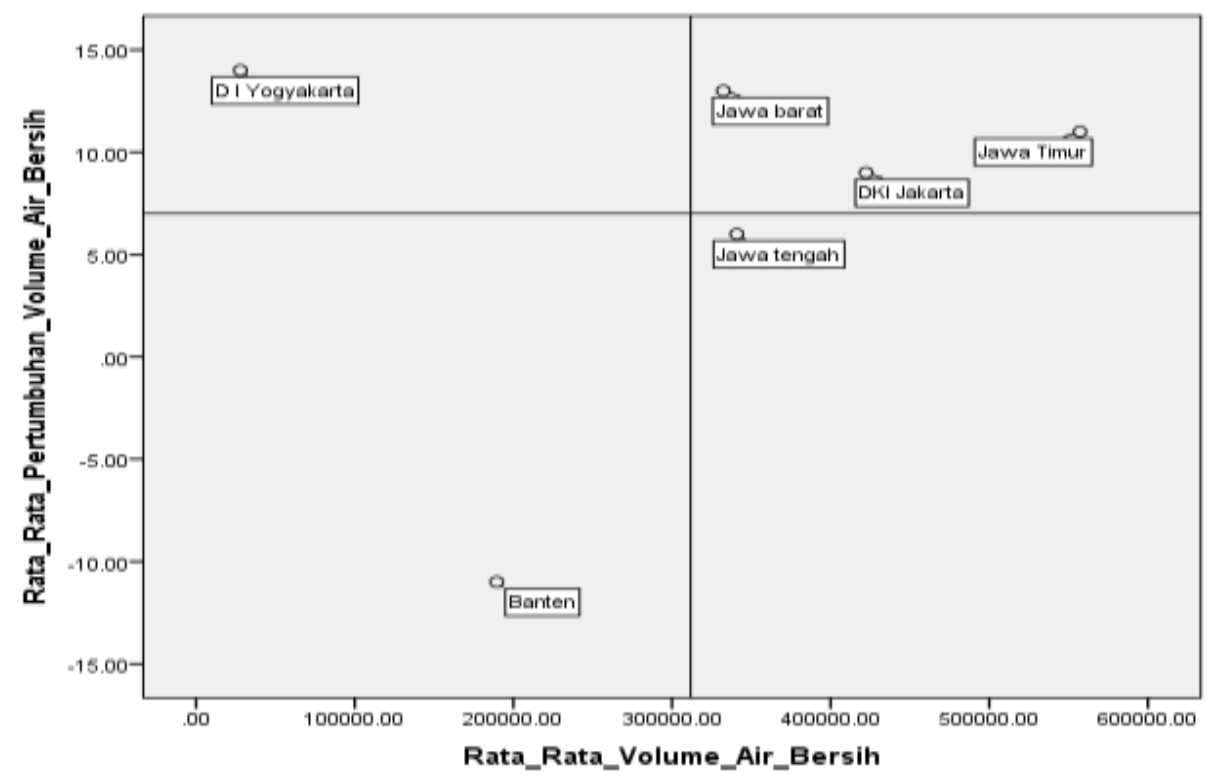

Gambar 11. Klasifikasi pertumbuhan distribusi volume air provinsi di Pulau Jawa tahun 2013 - 2017 menurut Tipologi Klassen.

Pada Gambar 12, tipologi klassen juga dapat dilihat bahwa sebagian besar air bersih minim didistribusikan di wilayah Indonesia Bagian Timur, bahkan jika dibandingkan dengan ratarata volume distribusi air bersih yang disalurkan ke luar Pulau Jawa pun beberapa provinsi di bagian Indonesia Timur seperti Papua, Papua Barat dan Nusa Tenggara Timur masih sangat minim ketersediaan air bersihnya.

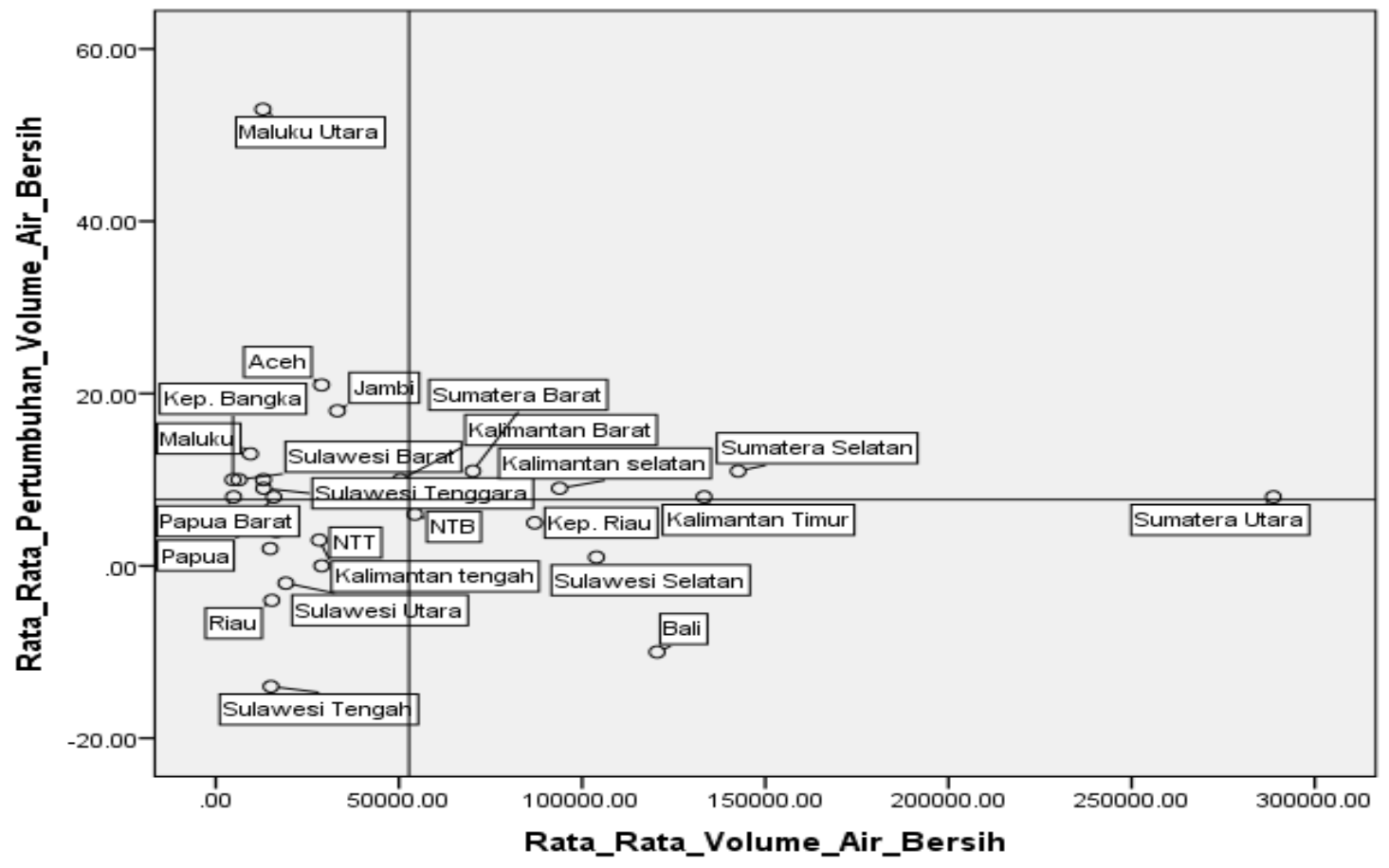

Gambar 12. Klasifikasi pertumbuhan distribusi volume air provinsi di luar Pulau Jawa tahun 2013 2017 menurut Tipologi Klassen. 


\section{Infrastruktur Jalan}

Infrastruktur jalan sangat penting dalam perekonomian karena angkutan darat sampai saat ini masih menjadi sistem transportasi utama di Indonesia. Pelayanan dan kapasitas jalan berkaitan dengan terselenggaranya mobilitas penduduk maupun barang dan jasa, menunjang aktivitas ekonomi dalam pembangunan. Saat ini jalan dalam kondisi baik lebih banyak dibangun di daerah luar Pulau Jawa.

Berdasarkan Gambar 13 dan 14, Tipologi klassen panjang jalan di Pulau Jawa lebih banyak terdapat pada kuadran III yaitu daerah relatif tertinggal dan IV yaitu daerah relatif maju tapi tertekan. Tingginya rata-rata panjang jalan pada provinsi Jawa Barat dan Jawa timur terjadi karena luas wilayah provinsi tersebut yang cukup besar. Hal yang menarik adalah rendahnya pertumbuhan panjang jalan yang ada di banten padahal Provinsi Banten memilki luas wilayah yang relatif lebih luas dari pada DKI Jakarta atau Daerah Istimewa Yogyakarta.

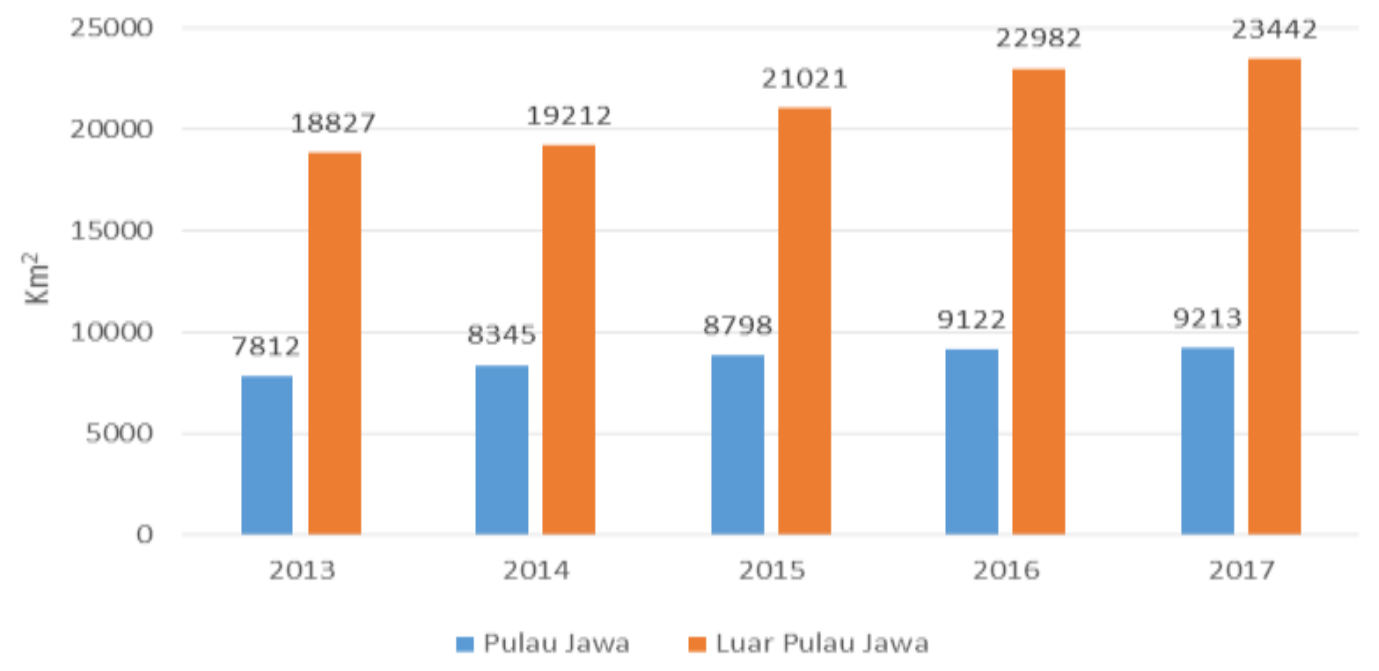

Sumber: BPS, 2018 (diolah)

Gambar 13. Panjang Jalan Kondisi Baik di Pulau Jawa dan luar Pulau Jawa 2013-2017

Secara teori pemerintah pusat dan pemerintah Provinsi Banten. Jalan merupakan infrastruktur daerah harus berkoordinasi untuk membangun yang sangat dibutuhkan bagi transportasi darat panjang jalan yang terdapat pada provinsi- yang berfungsi sebagai penghubung suatu provinsi yang ada di daerah kuadran III yaitu wilayah dengan wilayah lainnya. provinsi Daerah Istimewa yogyakarta dan

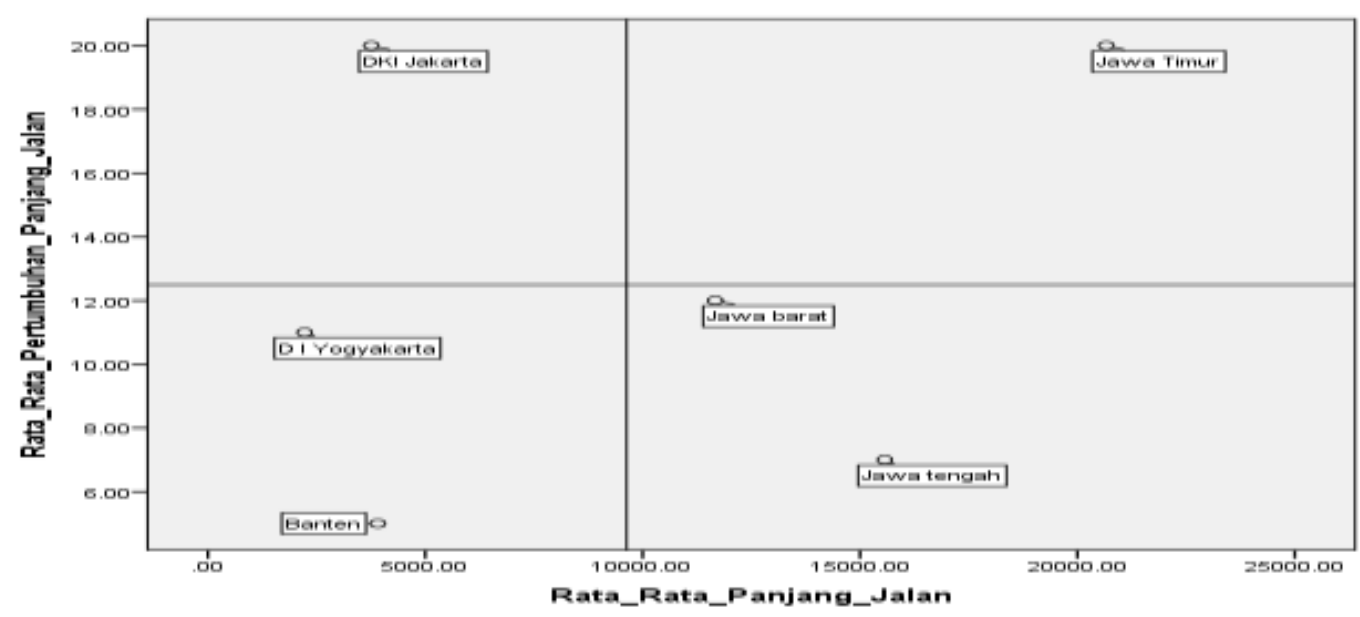

Gambar 14. Klasifikasi pertumbuhan panjang jalan provinsi di Pulau Jawa tahun 2013 - 2017 menurut Tipologi Klassen. 
Sementara itu untuk provinsi yang ada di luar Pulau Jawa saat ini rata-rata panjang jalan lebih banyak ada di wilayah III atau daerah relatif tertinggal. Hal ini akan berdampak negatif bagi perekonomian wilayah tersebut karena banyaknya provinsi yang tidak memilki ketersediaan jalan yang dapat digunakan untuk menggerakkan perekonomain. Dalam jangka panjang bahkan ini akan berdampak negatif terhadap perekomian Indonesia dan menyebabkan meningkatnya ketimpangan antar wilayah karena keterbatasan penyediaan infrastruktur transportasi pada wilayah tersebut.
Pemerintah dalam hal ini harus memberikan perhatian lebih, khususnya pada daerah yang memiliki keterbatasan dalam infrastruktur jalan atau transportasinya karena Infrastruktur jalan sangat penting dalam perekonomian mengingat faktanya angkutan darat sampai saat ini masih menjadi sistem transportasi utama di Indonesia. Program-program pembangunan jalan Trans Papua, Sumatera dan Kalimantan harus terus di optimalkan pembangunannya agar wilayahwilayah diluar Pulau Jawa dapat berkembang perekonomiannya

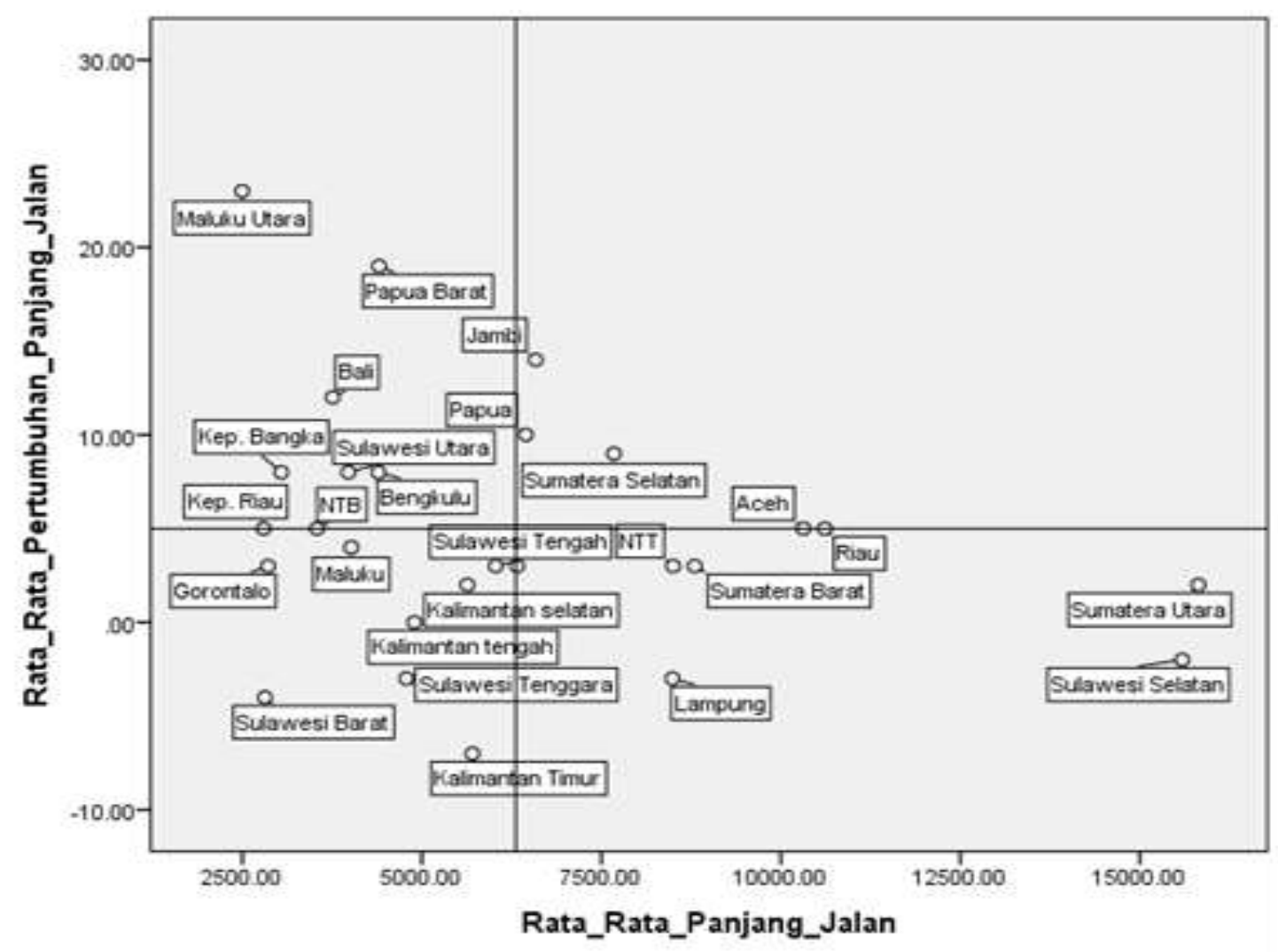

Gambar 15. Klasifikasi pertumbuhan panjang jalan provinsi di Pulau Jawa tahun 2013 - 2017 menurut Tipologi Klassen.

\section{Infrastruktur Pendidikan}

Salah satu faktor penting dalam keberhasilan pembangunan suatu negara adalah sumber daya manusia (SDM) yang berkualitas. Pendidikan merupakan salah satu komponen yang menentukan kualitas sumber daya manusia dan merupakan faktor utama yang dapat menentukan kemampuan seseorang dalam menyerap dan mengelola sumber perekonomian baik melalui kemajuan teknologi maupun kelembagaan. Jika dibandingkan saat ini rata-rata lama sekolah
Pulau Jawa lebih besar jika dibandingkan dengan luar Pulau Jawa.

Berdasarkan Gambar 16 hasil analisis tipologi klassen untuk jumlah sekolah dari berbagai jenjang pendidikan yang ada di Pulau Jawa, saat ini rata-rata jumlah sekolah lebih banyak ada pada wilayah I yaitu daerah cepat maju dan wilayah III yaitu daerah relatif tertinggal. Provinsi yang termasuk dalam wilayah relatif tertinggal adalah provinsi Daerah Istimewa Yogyakarta dan DKI Jakarta. 


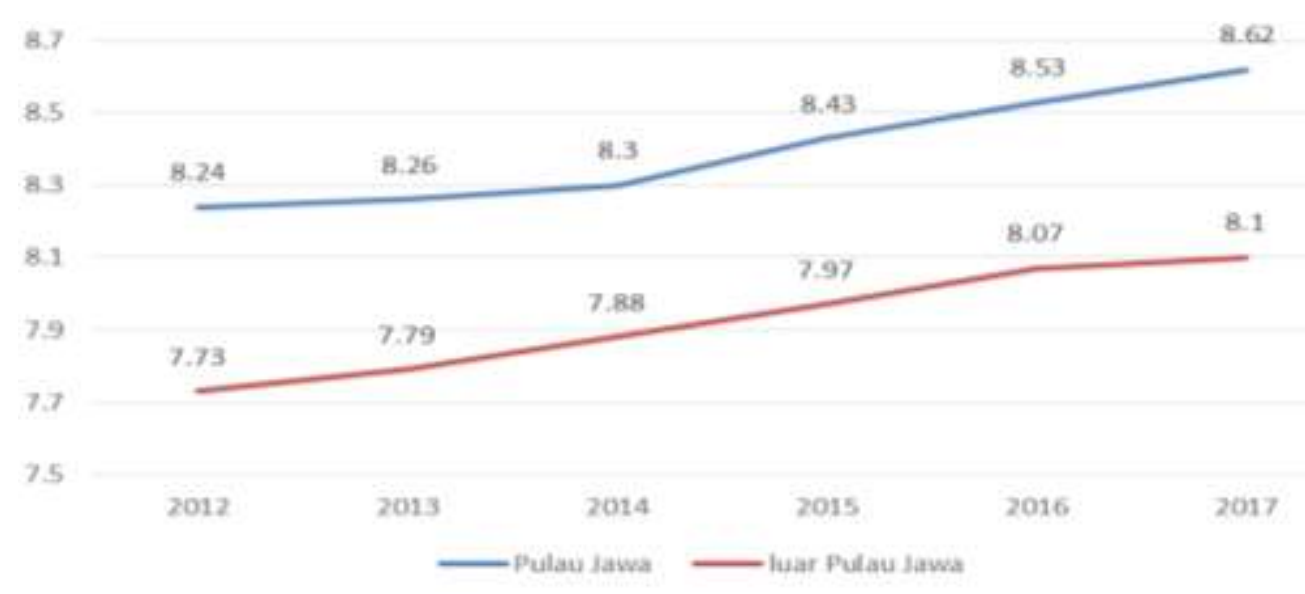

Sumber: BPS, 2018 (diubah)

Gambar 16. Rata-Rata Lama Sekolah Pulau Jawa dan luar Pulau Jawa.

Hal ini bertolak belakang dengan fakta bahwa Daerah Istimewa Yogyakarta menjadi salah satu kota pendidikan yang ada di Indonesia dan DKI Jakarta menjadi daerah dengan tingkat imigran tertinggi di Indonesia (BPS 2019). Keadaan ini terjadi karena luas wilayah Provinsi DKI Jakarta dan Daerah Istimewa Yogyakarta yang relatif lebih kecil dibandingkan dengan provinsi lainnya yang ada di Pulau Jawa. Secara umum rata-rata jumlah sekolah yang ada di Pulau Jawa lebih banyak daripada yang ada di luar Pulau Jawa hal ini sekaligus mengkonfirmasi alasan perbedaan yang tingginya rata-rata lama sekolah yang ada di Pulau Jawa.

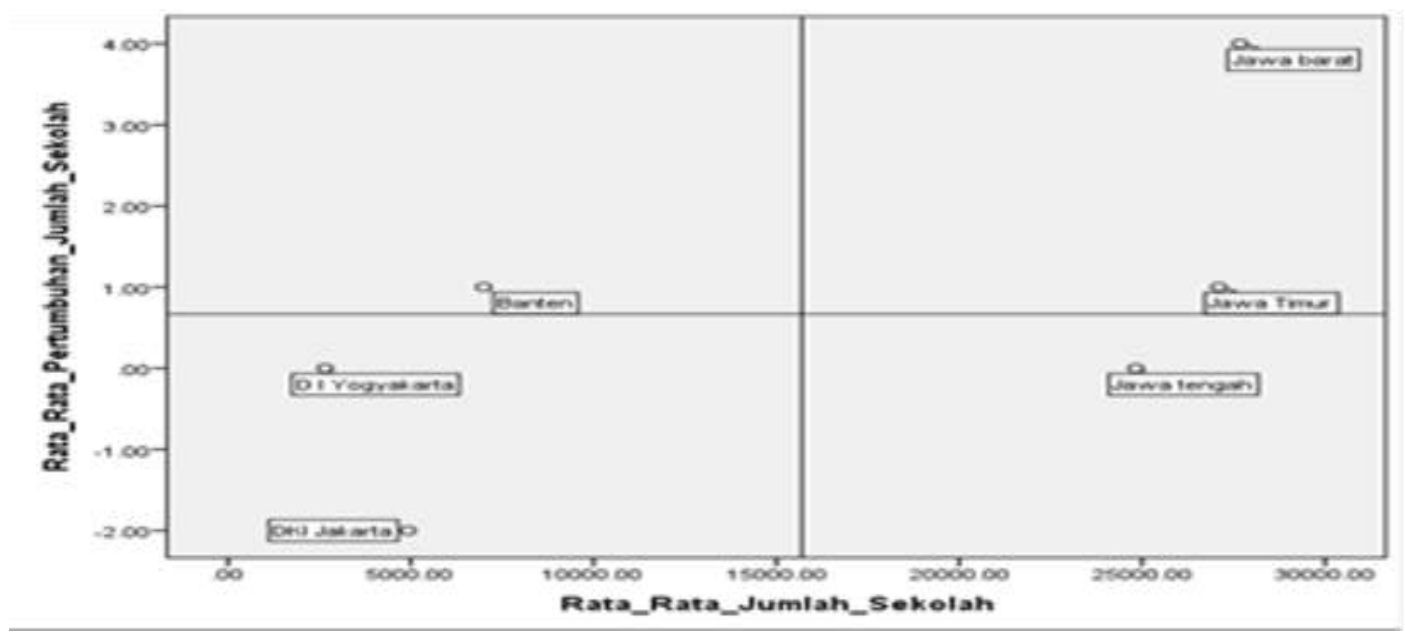

Gambar 17. Klasifikasi Jumlah Sekolah pada berbagai jenjang pendidikan di Pulau Jawa tahun 2013 2017 menurut Tipologi Klassen.

Berdasarkan gambar 17 hasil analisis pertumbuhan infrastruktur jumlah sekolah di provinsi yang ada di luar Pulau Jawa bahwa jumlah sekolah dari berbagai jenjang pendidikan cenderung terdapat pada kuadran III yaitu daerah tertinggal. Terdapat sekitar 11 dari 27 provinsi diluar Pulau Jawa yang berada di wilayah ini. Dalam waktu jangka panjang hal ini akan berdampak negatif bagi pertumbuhan ekonomi
Indonesia karena akan menghambat pembangunan dan meningkatkan kesenjangan diantara provinsi yang ada di Indonesia. Pemerintah dalam rangka melakukan pemerataan pendidikan sampai ke pelosok Indonesia harus mampu membangun infrastruktur sekolah sampai ke pelosok Indonesia terutama ke daerah-daerah tempat kantong kemiskinan berada saat ini (gambar18). 


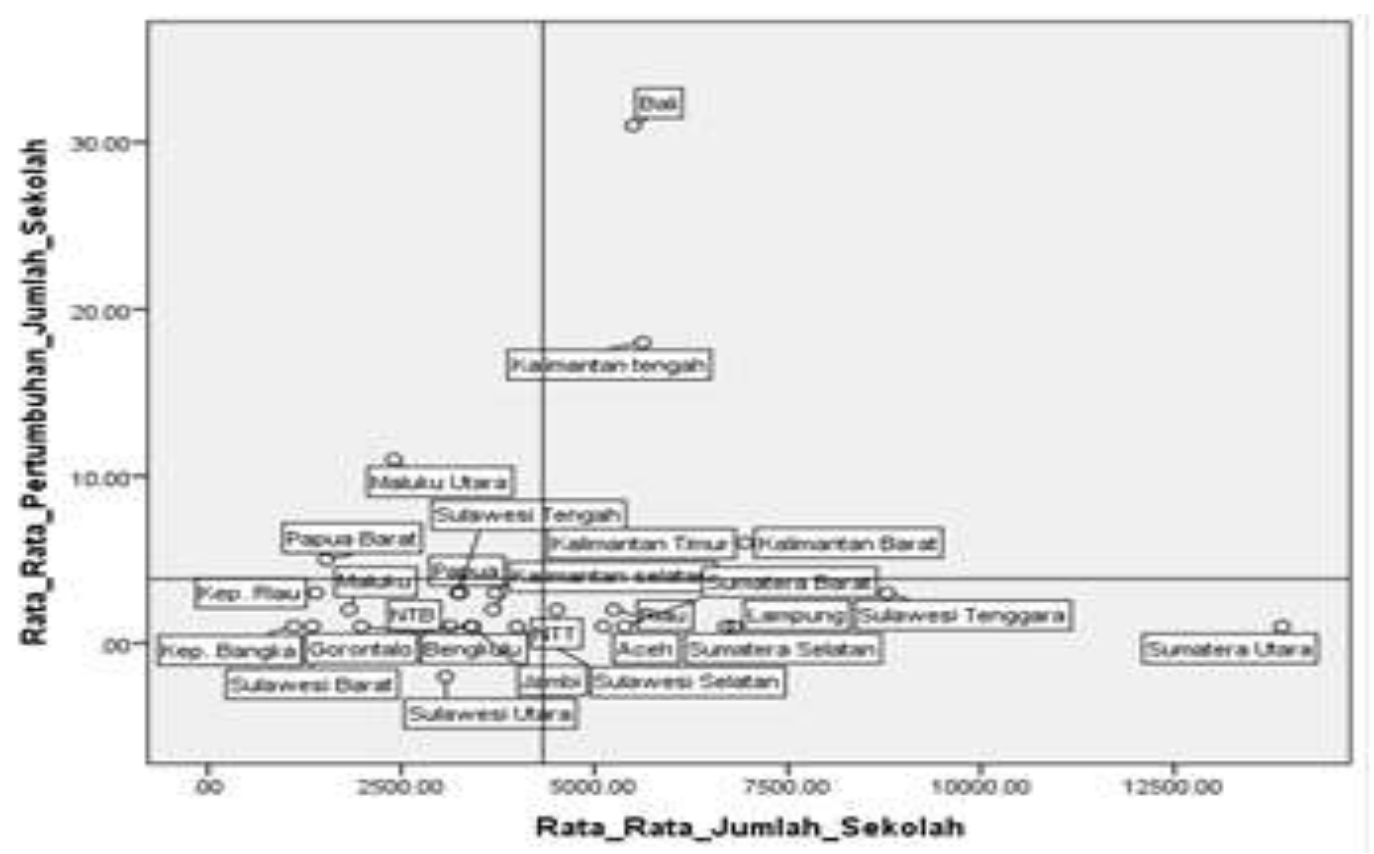

Gambar 18. Klasifikasi pertumbuhan infrastruktur sekolah diluar Pulau Jawa tahun 2013-2017 menurut Tipologi Klassen.

Hal penting lainnya yang juga harus diperhatikan adalah bagaimana pembangunan infrastruktur pendidikan yang ada selama ini juga harus diikuti dengan keterbukaan akses pendidikan terutama bagi masyarakat miskin yang sering kali tidak dapat "menikmati bangku sekolah" karena masalah keterbatasan dana atau tingginya biaya pendidikan. Pengadaan program Kartu Indonesia Pintar serta Beasiswa Bidik Misi harus terus di tingkatkan ketersediaannya. Hal ini penting agar target wajib belajar 12 tahun yang pemerintah canangkan dapat berjalan sesuai dengan rencana. (Tabel 2 dan 3).

Tabel 2. Hasil pendugaan parameter pertumbuhan ekonomi di Pulau Jawa.

\begin{tabular}{|c|c|c|c|}
\hline \multirow[t]{2}{*}{ Variabel eksogen } & \multicolumn{3}{|c|}{ Variabel Endogen : LogPDRB2010 } \\
\hline & Koefisien & Nilai Statistik & Probabilitas \\
\hline $\mathrm{C}$ & -4.871963 & -1.38931 & 0.1817 \\
\hline LIS & 0.003633 & 0.416057 & 0.6823 \\
\hline LNAIR & $-0.003636^{*}$ & -1.99913 & 0.0609 \\
\hline LNJALAN & $0.017496 * *$ & 2.359501 & 0.0298 \\
\hline LNKES & $2.603494 * *$ & 4.128536 & 0.0006 \\
\hline LNPEND & $4.257506^{* *}$ & 12.76713 & 0.0000 \\
\hline TK & 0.005479 & 0.968439 & 0.3457 \\
\hline DW stat 1.907863 & 97 & & \\
\hline
\end{tabular}




\section{Infrastruktur Listrik}

Variabel infrastruktur listrik pada penelitian ini diwakili oleh rasio elektrifikasi, untuk Pulau Jawa variabel infrastruktur listrik tidak signifikan memengaruhi tingkat PDRB, sementara itu di luar Pulau Jawa rasio elektrifikasi berpengaruh signifikan positif terhadap kenaikan tingkat PDRB. Kenaikan rasio elektrifikasi sebanyak 1 persen akan menaikkan tingkat PDRB sebanyak 0.223512 persen (ceteris paribus).

Saat ini distribusi listrik di luar Pulau Jawa masih cukup minim. Rasio elektrifikasi listrik yang ada di luar Pulau Jawa masih tergolong cukup rendah terutama beberapa provinsi di bagian Indonesia timur seperti Provinsi Nusa Tenggara Timur dan sebagian besar daerah di Pulau Papua. Penelitian ini sejalan dengan penelitian Prasetyo dan Firdaus (2009) dimana hasil penelitiannya Menjelaskan bahwa ketersediaan listrik positif berpengaruh terhadap tingkat pertumbuhan ekonomi Indonesia. Hasil penelitian yang dilakukan Ria (2018) dalam penelitiannya menunjukkan rasio elektrifikasi dapat menggenjot peningkatan PDRB di sebagian besar daerah yang ada di Indonesia timur.

Tabel 3. Hasil pendugaan parameter pertumbuhan ekonomi di luar Pulau Jawa.

\begin{tabular}{|c|c|c|c|}
\hline \multirow[t]{2}{*}{ Variabel eksogen } & \multicolumn{3}{|c|}{ Variabel Endogen : LogPDRB2010 } \\
\hline & Koefisien & Nilai Statistik & Probabilitas \\
\hline $\mathrm{C}$ & 10.67338 & 31.19767 & 0.0000 \\
\hline LIS & $0.223512^{* *}$ & 4.325027 & 0.0000 \\
\hline LNAIR & $0.003202 * *$ & 4.166334 & 0.0001 \\
\hline LNJALAN & $0.068344 * *$ & 4.117889 & 0.0001 \\
\hline LNKES & 0.057544 & 1.401782 & 0.1640 \\
\hline LNPEND & $2.296145^{* *}$ & 9.062981 & 0.0000 \\
\hline TK & 0.005556 & 0.949595 & 0.3446 \\
\hline
\end{tabular}

DW stat $1.401469 \quad \mathrm{R}^{2} 0.9994$

\section{Infrastruktur Air}

Variabel infrastruktur air yang digunakan pada penelitian ini signifikan pengaruhnya terhadap tingkat PDRB, namun dengan koefisien yang berbeda. Pada Pulau Jawa kenaikan distribusi volume air bersih oleh perusahaan air minum signifikan berpengaruh negatif terhadap tingkat PDRB Pulau Jawa, dimana peningkatan volume air sebanyak 1 persen akan mengurangi tingkat PDRB yang ada di Pulau Jawa sebanyak 0.003636 persen dengan asumsi ceteris paribus.

Hal ini tidak sejalan dengan hipotesis awal yang digunakan pada penelitian, ini diakibatkan oleh besarnya dana atau biaya subsidi PDAM yang dikeluarkan pemerintah yang tidak sebanding dengan kontribusi pengadaan air bersih tersebut terhadap pertumbuhan ekonomi. Pada awal tahun 2019 saja pemerintah lewat Kementrian PUPR menganggarkan 52 triliun dari total APBN serta menganggarkan dana hibah sebanyak 850 milyar untuk penyediaan air bersih, biaya tersebut belum termasuk dengan biayabiaya hibah dari negara lain, sebagian besar dana subsidi tersebut dialokasikan untuk provinsiprovinsi di Pulau Jawa karena tingginya jumlah masyarakat yang tinggal diwilayah tersebut. 
Hasil ini sejalan juga dengan penelitian yang dikerjakan warsilan (2015) yang membuktikan jika distribusi air oleh PDAM memengaruhi pertumbuhan ekonomi yang di Kota Samarinda. Hasil ini sejalan juga dengan penelitian yang dikerjakan Sarah (2018) yang menunjukkan jika pembangunan infrastruktur air dapat meningkatkan pertumbuhan ekonomi dan mengurangi kemiskinan di mayoritas kota dan desa yang ada di Indonesia.

\section{Infrastruktur Jalan}

Pada Pulau Jawa juga di luar Pulau Jawa infrastruktur transportasi diwakilkan oleh variabel keadaan jalan baik sama-sama signifikan memengaruhi tingkat PDRB. Di Pulau Jawa penambahan panjang jalan dalam keadaan baik sebanyak 1 persen akan menambah tingkat PDRB sebanyak 0.017496 persen dengan asumsi ceteris paribus. Bagi daerah di luar Pulau Jawa penambahan panjang jalan dalam keadaan baik sebanyak 1 persen akan menambah tingkat PDRB atau pertumbuhan ekonomi sebanyak 0.068344 persen ceteris paribus. Jalan merupakan bagian penting dari perekonomian, keberadaan jalan membuat mobilitas barang maupun jasa dapat lebih cepat sampai ke tujuannya. Infrastruktur jalan merangsang tumbuhnya wilayah baru dan menggerakan ekonomi disekitar daerah yang bersangkutan.

Jalan dalam keadaan baik juga membuat biaya transportasi dapat lebih murah. Keberadaan jalan yang baik mendorong pertumbuhan ekonomi karena membuat akses yang lebih besar kepada sumber daya produksi, pasar maupun modal. Jalan menjadi salah satu alasan penting dalam mendorong pemerataan ekonomi yang ada di suatu wilayah. Pembangunan infrastruktur jalan sampai ke pelosok Indonesia menjadi salah satu alternatif dalam rangka pemerataan ekonomi

Temuan pada penelitian ini mendukung studi penelitian oleh Fan dan Kang (2004) yang menemukan jika pembangunan jalan berdampak baik pada tingkat pertumbuhan ekonomi di Pulau Sumatera dan Kalimantan. Serta penelitian yang dikerjakan Wibowo (2018) dimana dalam penelitiannya menunjukkan pembangunan jalan di Pulau Sumatera dan Pulau Jawa mendorong pertumbuhan ekonomi.

\section{Infrastruktur Pendidikan}

Pada penelitian ini variabel pendidikan diwakili dengan nilai rata-rata lama sekolah, Variabel ini di Pulau Jawa maupun di luar Pulau Jawa sama-sama berpengaruh signifikan positif terhadap tingkat PDRB. Dimana peningkatan rata-rata lama sekolah sebanyak 1 persen di Pulau Jawa akan meningkatkan PDRB sebanyak 4.257506 persen, ceteris paribus. Sementara itu untuk di luar Pulau Jawa, peningkatan rata-rata lama sekolah akan meningkatkan PDRB sebanyak 2.296145 persen, ceteris paribus. Hubungan antara pendidikan dengan tingkat PDRB akan menunjukkan perbandingan sebanding, semakin tinggi latar belakang pendidikan seseorang maka akan bepengaruh juga pada peningkatan produktivitas sehingga dapat memperoleh upah yang lebih tinggi dan pada akhirnya akan berkontribusi pada peningkatan nilai PDRB.

Saat ini rata-rata lama sekolah di Indonesia berkisar antara 8 sampai 9 tahun atau kelas 2 SMP sampai 3 SMP. Nilai ini masih sangat jauh dari target pemerintah terutama program wajib belajar 12 tahun. Pendirian atau penambahan jumlah sekolah secara fisik penting untuk terus dilakukan pemerintah tetapi yang juga harus dipastikan adalah bagaimana penambahan jumlah sekolah tersebut juga diikuti dengan jaminan akses pendidikan oleh masyarakat miskin. Penelitian yang dilakukan Fadila (2018) menunjukkan bahwa pendidikan menjadi faktor yang sangat penting dalam mengurangi tingkat kemiskinan yang terjadi di Pulau Jawa juga di luar Pulau Jawa. Penelitian yang juga dilakukan Loredana dan Andrei (2015) yang menjelaskan kualitas pendidikan berpengaruh pada peningkatan mutu modal manusia yang akan mendorong produktivitas dan berkontribusi terhadap pertumbuhan ekonomi. 
Tabel 4. Hasil pendugaan parameter kemiskinan di Pulau Jawa.

\begin{tabular}{lccc}
\hline Variabel eksogen & \multicolumn{3}{c}{ Variabel Endogen : LOGPENDUDUKMISKIN } \\
\cline { 2 - 4 } & Koefisien & Nilai Statistik & Probabilitas \\
\cline { 2 - 4 } C & -33.5638 & -1.41808 & 0.1724 \\
Gini & 0.467788 & 0.952541 & 0.3528 \\
LnAHH & 8.660715 & 1.704619 & 0.1046 \\
LnPOP & $1.886074^{*}$ & 1.806160 & 0.0868 \\
LnUMP & 0.108534 & 0.128712 & 0.4096 \\
LnPDRB & $-1.2216^{* *}$ & -2.43596 & 0.0249 \\
\hline
\end{tabular}

\section{Infrastruktur Kesehatan}

Ketersediaan Rumah sakit dan Puskesmas adalah variabel yang digunakan untuk mewakili infrastruktur kesehatan pada penelitian ini. Di Pulau Jawa penambahan jumlah rumah sakit serta puskesmas berpengaruh signifikan positif terhadap tingkat PDRB dimana peningkatan jumlah rumah sakit dan puskesmas sebanyak 1 persen akan menambah PDRB sebanyak 2.603494 persen, ceteris paribus.

Beberapa hasil penelitian mendukung penelitan ini, diantaranya adalah penelitian yang dikerjakan Sukmawati (2016) dimana pada penelitiannya membuktikan bahwa pembangunan rumah sakit memiliki pengaruh positif terhadap tingkat PDRB dan pengentasan angka kemiskinan di Indonesia. Hasil Studi ini serupa dengan penelitian yang dikerjakan oleh Nuraliyah (2011) pembangunan puskesmas di Pulau Jawa akan mendorong pertumbuhan ekonomi di wilayah tersebut. Hasil penelitian oleh Fatchurrohman (2018) juga sejalan dengan penelitian ini yang menyimpulkan bahwa ketersediaan rumah sakit sebagai infrastruktur kesehatan berpengaruh pada tingkat PDRB di Indonesia. (Tabel 4 dan 5)

Tabel 5. Hasil pendugaan parameter kemiskinan di luar Pulau Jawa.

\begin{tabular}{llcl}
\hline Variabel eksogen & \multicolumn{3}{c}{ Variabel Endogen : LOGPENDUDUKMISKIN } \\
\cline { 2 - 4 } & Koefisien & Nilai Statistik & Probabilitas \\
\cline { 2 - 4 } C & 9.904911 & 0.983974 & 0.3274 \\
Gini & -0.202956 & -1.16497 & 0.2467 \\
LnAHH & $-4.62142^{*}$ & -1.88637 & 0.0621 \\
LnPOP & $-0.86602 * *$ & -3.11149 & 0.0024 \\
LnUMP & 0.240756 & 2.989326 & 0.2035 \\
LnPDRB & $-0.51109 * *$ & -2.21765 & 0.0288
\end{tabular}




\section{Angka Harapan Hidup}

Hasil studi ini menunjukkan jika variabel angka harapan hidup tidak memengaruhi angka penduduk miskin di Pulau Jawa, namun di luar Pulau Jawa variabel angka harapan hidup berpengaruh negatif pada angka kemiskinan, peningkatan angka harapan hidup sebanyak 1 persen akan menekan angka kemiskinan sebanyak 4.621423 persen, ceteris paribus. Hal ini terjadi karena cukup banyaknya penduduk usia lanjut yang masih bekerja di luar Pulau Jawa (BPS 2018). Sebanyak 58 persen dari total penduduk usia lanjut di luar Pulau Jawa masih bekerja, sehingga di usia tuanya pun penduduk lansia tersebut masih tetap produktif dan memenuhi kebutuhannya sendiri, selain itu ratarata rasio ketergantungan usia lansia yang ada di luar Pulau Jawa juga lebih sedikit daripada di Pulau Jawa. Pada awal tahun 2018 rasio ketergantungan penduduk usia lanjut sebesar 11.47, nilai ini lebih kecil dari pada rata-rata rasio ketergantungan penduduk lanjut usia di Indonesia pada saat itu yaitu sebanyak 14.47 tahun (BPS 2019). Hal ini menunjukkan besarnya rasio ketergantungan penduduk lansia di luar Pulau Jawa lebih besar dari pada di Pulau Jawa, sehingga semakin besar juga beban ketergantungan yang harus di rasakan oleh penduduk usia produktif di luar Pulau Jawa.

Beberapa hasil studi mendukung penelitan ini, diantaranya adalah penelitian yang dikerjakan Hapsari (2019) dimana beliau melakukaan penelitian tentang faktor memengaruhi angka kemiskinan penduduk yang ada di Indonesia dari tahun 2010 sampai 2017, penelitiannya menunjukkan variabel angka harapan hidup signifikan negatif pengaruhnya pada tingkat kemiskinan yang ada di Indonesia. Studi ini juga memiliki jawaban yang sama dengan studi Amelia (2012) yang menunjukkan angka harapan hidup berpengaruh signifikan negatif pada tingkat kemiskinan di Nusa Tenggara Timur.

\section{Jumlah Penduduk}

Pada provinsi di Pulau Jawa maupun di luar Pulau Jawa tingkat kemiskinannya sama-sama dipengaruhi oleh variabel populasi jumlah penduduk dengan pengaruh yang berbeda, di Pulau Jawa peningkatan jumlah penduduk sebesar 1 persen akan menambah angka kemiskinan sebesar 1.886074 persen, ceteris paribus. Hal ini karena sudah padatnya penduduk Indonesia yang tinggal di Pulau Jawa sehingga penambahan jumlah penduduk lagi akan meningkatkan kemiskinan.

Pada tahun 2018 lebih dari 50 persen penduduk Indonesia tinggal saat ini di Pulau Jawa (BPS 2019) yang sebenarnya hanya 6.7 persen dari luas wilayah Indonesia. Hal ini diperburuk dengan penduduk yang melakukan migrasi ke Pulau Jawa tidak memiliki tingkat pendidikan dan soft skill yang cukup baik sehingga justru meningkatkan angka pengangguran di Pulau Jawa. Pada awal tahun 2018 angka pengangguran di Pulau Jawa juga lebih besar dari pada di luar Jawa (BPS 2019).

Di Pulau Jawa pemerintah harus terus mengupayakan implementasi program-program migrasi penduduk yang dapat mengurangi padatnya jumlah penduduk. Cara lain yang dapat pemerintah lakukan adalah dengan memberikan insentif kepada pengusaha-pengusaha muda serta pelaku usaha umkm dalam menjalankan usaha yang dimilikinya. Hal ini perlu dilakukan agar tenaga kerja yang menganggur dapat diserap oleh umkm sehingga dapat mengurangi angka pengangguran dan kemiskinan. Pada faktanya sebagian besar tenaga kerja Indonesia saat ini bekerja di sektor informal sehingga keberadaan umkm harus terus didukung pemerintah keberadaanya sebagai salah satu "roda" penggerak ekonomi Indonesia.

Di luar Pulau Jawa penambahan jumlah penduduk sebanyak 1 persen akan mengurangi jumlah penduduk miskin sebanyak 0.866028 persen, dengan asumsi ceteris paribus. Banyaknya penduduk yang memilih untuk tinggal di Pulau Jawa bukan saja dapat meningkatkan penduduk miskin yang ada di daerah tersebut tetapi juga mengurangi sumber daya manusia yang potensial dalam mengembangkan daerahnya masing-masing. Hal ini jika dibiarkan akan menimbulkan ketimpangan wilayah. Program migrasi untuk menekan jumlah penduduk saat ini masih terus diupayakan pemerintah dan harus terus ditingkatkan kinerjanya agar penduduk yang ada di Pulau Jawa dapat terus dikurangi jumlahnya 
dan populasi penduduk dapat menyebar secara merata ke seluruh Indonesia.

\section{PDRB/Tingkat Pertumbuhan ekonomi}

Variabel PDRB merupakan variabel utama yang menjadi dasar dan dibahas pada penelitian ini. Dimana pertumbuhan ekonomi merupakan instrumen yang digunakan untuk mengevaluasi kinerja pembangunan infrastruktur terhadap pengentasan kemiskinan yang ada. Bagi provinsi yang ada di Pulau Jawa variabel PDRB/ pertumbuhan ekonomi memiliki pengaruh positif pada angka kemiskinan yang ada di wilayah tersebut. Peningkatan PDRB sebanyak 1 persen akan mengurangi kemiskinan yang ada di Pulau Jawa sebanyak 1.221628 persen, ceteris paribus. Sementara itu untuk wilayah di luar Pulau Jawa peningkatan PDRB sebanyak 1 persen akan mengurangi taraf kemiskinan sebanyak 0.511091 persen, ceteris paribus. Pertumbuhan ekonomi menjadi salah satu cara dalam mereduksi angka kemiskinan di Indonesia.

Hal ini sejalan dengan konsep dan teori dimana dorongan pertumbuhan ekonomi berpotensi untuk mengurangi angka kemiskinan di suatu wilayah. Hasil dari studi ini serupa pada studi yang dilakukan Prasetyo (2010) menyimpulkan jika ada hubungan negatif antara tingkat PDRB dan angka kemiskinan di Indonesia di tahun penelitian 2010 sampai 2016, juga sejalan pada studi yang dilakukan Ravallion (2006) yang menyimpulkan bahwa pertumbuhan ekonomi berpengaruh pada pengurangan angka kemiskinan di Negara India dan China pada penelitian yang dilakukan di tahun 1980-2000.

\section{SIMPULAN DAN SARAN}

\section{Simpulan}

1. Penelitian ini menunjukkan bahwa pembangunan infrastruktur memengaruhi kemiskinan yang ada di Pulau Jawa dan luar Pulau Jawa.

2. Infrastruktur yang memengaruhi pertumbuhan PDRB di Pulau Jawa adalah distribusi air bersih, panjang jalan, jumlah rumah sakit dan puskesmas serta rata-rata lama sekolah. Di luar Pulau Jawa infrastruktur yang memengaruhi pertumbuhan PDRB adalah distribusi volume air bersih, panjang jalan, rasio elektrifikasi dan rata-rata lama sekolah.

3. Pertumbuhan ekonomi mampu mengurangi tingkat kemiskinan baik di Pulau Jawa maupun luar Pulau Jawa.

\section{Saran}

Dari hasil penelitian ini menunjukkan bahwa pembangunan infrastruktur masih cukup minim dibangun di daerah tertinggal, sehingga pemerintah didorong untuk dapat membangun infrastruktur sampai ke pelosok Indonesia, pembangunan infrastruktur yang tepat sasaran tersebut bertujuan agar mendorong pertumbuhan ekonomi khususnya di wilayah yang terdapat diluar Pulau Jawa.

Pembangunan infrastruktur secara fisik di seluruh Indonesia juga harus diikuti dengan ketersediaan akses terhadap infrastruktur itu sendiri oleh penduduk miskin misalnya dengan memberikan jaminan pendidikan dan kesehatan yang murah bahkan gratis ke penduduk miskin yang ada di Indonesia. Pemerintah juga didorong untuk terus dapat melakukan migrasi penduduk agar tidak terjadi penumpukan jumlah penduduk di Pulau Jawa.

\section{DAFTAR PUSTAKA}

Amrullah T. 2006. Analisis Pengaruh Pembangunan Infrastruktur terhadap Pertumbuhan Ekonomi Regional di Indonesia [tesis]. Jakarta (ID). Universitas Indonesia.

Astridasari Sarah. 2018. Pengaruh pembangunan infrastruktur terhadap tingkat kemiskinan dan pemerataan di Indonesia [Skripsi]. Bogor (ID): Institut Pertanian Bogor.

[BPS] Badan Pusat Statistik. 2018. Migrasi Seumur Hidup dan Migrasi Risen Pulau Jawa. [Internet]. [diunduh 2019 April 21]. Tersedia pada: https://www.bps.go.id/. 2018. PDRB atas dasar harga konstan provinsi di Indonesia 2014-2017. [Internet]. [diunduh 2019 juni 11]. Tersedia pada: https://www.bps.go.id/

2018. Pembangunan Infrastruktur Indonesia[Internet]. [diunduh 2019 mei 03]. Tersedia pada: https://www.bps.go.id/ 
2018. Penduduk Miskin di Indonesia. [Internet]. [diunduh 2019 April 21]. Tersedia pada: https://www.bps.go.id/ 2018. Statistik Air Bersih 2012-2017. [Internet]. [diunduh 2019 April 21]. Tersedia pada: https://www.bps.go.id/ 2014. Profil Statistik Kesehatan Indonesia 2013. [Internet]. [diunduh 2019 Januari 29]. Tersedia pada: https://www.bps.go.id/ 2015. Profil Statistik Kesehatan Indonesia 2014. [Internet]. [diunduh 2019 Januari 29]. Tersedia pada: https://www.bps.go.id/ 2016. Profil Statistik Kesehatan Indonesia 2015. [Internet]. [diunduh 2019 Januari 29]. Tersedia pada: https://www.bps.go.id/ 2017. Profil Statistik Kesehatan Indonesia 2016. [Internet]. [diunduh 2019 Januari 29]. Tersedia pada: https://www.bps.go.id/ 2018. Profil Statistik Kesehatan Indonesia 2017. [Internet]. [diunduh 2019 Januari 29]. Tersedia pada: https://www.bps.go.id/ 2014. Profil Statistik Pendidikan 2013. [Internet]. [diunduh 2019 Februari 16]. Tersedia pada: https://www.bps.go.id/ 2015. Profil Statistik Pendidikan 2014. [Internet]. [diunduh 2019 Februari 16]. Tersedia pada: https://www.bps.go.id/ 2016. Profil Statistik Pendidikan 2015. [Internet]. [diunduh 2019 Februari 16]. Tersedia pada: https://www.bps.go.id/ 2017. Profil Statistik Pendidikan 2016. [Internet]. [diunduh 2019 Februari 16]. Tersedia pada: https://www.bps.go.id/ 2018. Profil Statistik Pendidikan 2017. [Internet]. [diunduh 2019 Februari 16]. Tersedia pada: https://www.bps.go.id 2014. Profil Statistik Transportasi Darat 2013. [Internet]. [diunduh 2019 Januari 09]. Tersedia pada: https://www.bps.go.id/ 2015. Profil Statistik Transportasi Darat 2014. [Internet]. [diunduh 2019 Januari 09]. Tersedia pada: https://www.bps.go.id/ 2016. Profil Statistik Transportasi Darat 2015. [Internet]. [diunduh 2019 Januari 09]. Tersedia pada: https://www.bps.go.id/ 2017. Profil Statistik Transportasi Darat 2016. [Internet]. [diunduh 2019 Januari 09]. Tersedia pada: https://www.bps.go.id/
2018. Statistik Indonesia 2017. [Internet]. [diunduh 2019 Januari 09]. Tersedia pada: https://www.bps.go.id/. 2019. Statistik Indonesia 2018. [Internet]. [diunduh 2019 Juni 09]. Tersedia pada: https://www.bps.go.id/

Calderon C, Serven L. 2004. The Effects of Infrastructure Development on Growth and Income Distribution. Policy ResearchWorking Paper. 3400: 95-118. https://openknowledge.worldbank.org/hand le/10986/14136

Chotia dan Rao. 2016. Investigating the interlinkages between infrastructure development, poverty and rural-urban income inequality Evidence from BRICS nations. Studies in Economics and Finance, Vol. 34 Issue: 4, pp.466-484. https://ideas.repec.org/s/eme/sefpps.html

Fadila AR. 2018. Membandingkan Pengaruh Pendidikan Terhadap Kemiskinan Di Wilayah Jawa Dan Luar Jawa Serta Implikasi Kebijakannya [Skripsi]. Bogor (ID): Institut Pertanian Bogor.

Fatchurrohman MA. 2018. Daya Tanggap Pertumbuhan Ekonomi Wilayah terhadap Pembangunan Infrastruktur di Indonesia [Skripsi]. Bogor (ID): Institut Pertanian Bogor.

Loredana P, Andrei A. 2015. Human CapitalThe effect of education on economic growth within the european union. Studia universitatis economics series: 35-44. https://content.sciendo.com/view/journals/s ues/25/3/article-p35.xml

Prasetyo RB, Firdaus M. 2009. Pengaruh Infrastruktur pada Pertumbuhan Ekonomi Wilayah di Indonesia. Jurnal Ekonomi dan Kebijakan Pembangunan. 2 (2): 222-236. https://fem.ipb.ac.id/j/JEKP\%20vol2\%20n o2\%20mei\%202009\%20$\% 20$ Pengaruh $\% 20$ Infrastruktur $\% 20 \mathrm{Pada} \%$ 20Pertumbuhan.pdf

Priyarsono. 2012. Pengaruh Infrastruktur terhadap kemiskinan Indonesia [Tesis]. Bogor (ID): Institut Pertanian Bogor.

Ravallion M. 2001. Growth, Inequality, and Poverty: Looking Beyond Averages.World Development. 29 (11): 1803-1815. 
http://siteresources.worldbank.org/INTPGI/ Resources/13996 MR2.pdf

Ria Jayanthi. 2018. Dampak Pembangunan Infrastruktur Listrik di Indonesia terhadap Tingkat Kemiskinan dan Distribusi Pendapatan [Tesis]. Bogor (ID): Institut Pertanian Bogor.

Todaro MP, Smith SC. 2006. Pembangunan Ekonomi Edisi Kesembilan. Terjemahan. Jakarta (ID): Erlangga.

Warsilan, Noor Akhmad. 2015. Peranan infrastruktur terhadap pertumbuhan ekonomi dan implikasi pada kebijakan pembangunan di kota samarinda.
MIMBAR, Jurnal Sosial dan Pembangunan Vol. 31, No. 2 (Desember, 2015): 359-366. https://www.researchgate.net/publication/3 22148709_Peranan_Infrastruktur_terhadap _Pertumbuhan_Ekonomi_dan_Implikasi_p ada Kebijakan Pembangunan di Kota Sa marinda

Wibowo T. 2018. Membandingkan Dampak Pembangunan Jalan terhadap Kemiskinan di Jawa dan Sumatera serta Implikasi Kebijakan [Skripsi]. Bogor (ID): Institut Pertanian Bogor.

World Bank. 1994. World Development Report 1994: Infrastructure for Development. 